Portland State University

PDXScholar

1989

\title{
Something old, something new : marriage customs among the Druze in the Shouf Mountains of Lebanon
}

Nancy Scarlette Beaini

Portland State University

Follow this and additional works at: https://pdxscholar.library.pdx.edu/open_access_etds

Part of the Near and Middle Eastern Studies Commons, and the Social and Cultural Anthropology Commons

Let us know how access to this document benefits you.

\section{Recommended Citation}

Beaini, Nancy Scarlette, "Something old, something new : marriage customs among the Druze in the Shouf Mountains of Lebanon" (1989). Dissertations and Theses. Paper 3873.

https://doi.org/10.15760/etd. 5760

This Thesis is brought to you for free and open access. It has been accepted for inclusion in Dissertations and Theses by an authorized administrator of PDXScholar. Please contact us if we can make this document more accessible: pdxscholar@pdx.edu. 
AN ABSTRACT OF THE THESIS OF Nancy Scarlette Beaini for the Master of Arts in Anthropology presented May 2, 1989.

Title: Something old, Something New: Marriage Customs Among the Druze in the Shouf Mountains of Lebanon

APPROVED BY MEMBERS OF THE THESIS COMMITTEE:

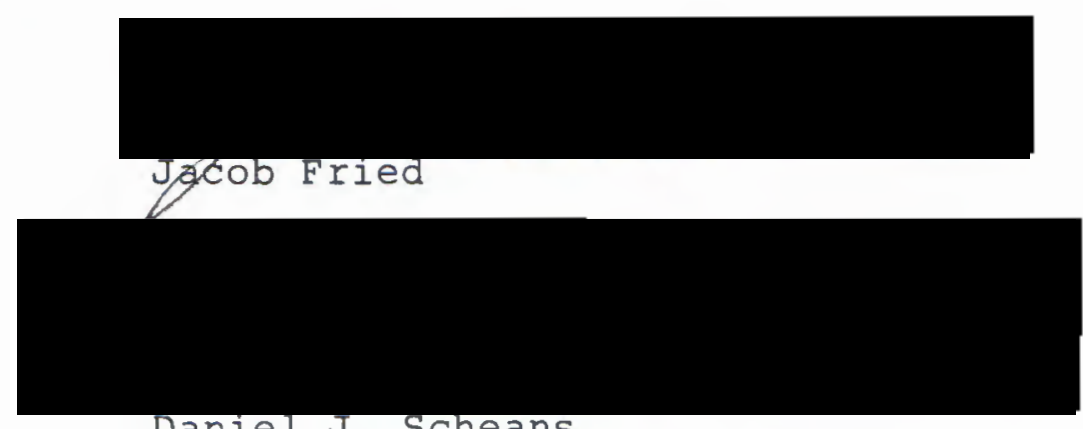

Danie1 J. Scheans

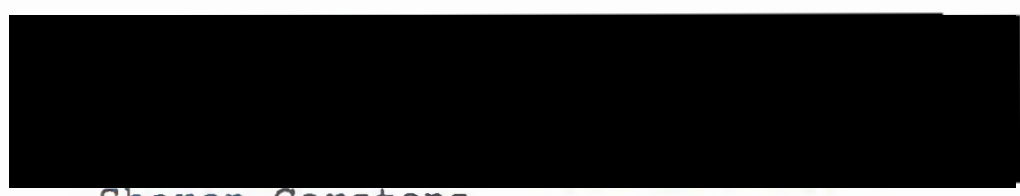

Sharon Carstens

Grant Farr

In researching the currently available literature, it can be seen that a descriptive ethnography of marriage customs has not been written for an ethnic minority in the Middle East called the Druze. A substantive, fine-grained ethnography that investigates Druze marriage customs is 
needed in the slowly-growing body of literature on Druze society and culture.

The focus of this research was to obtain, specifically, data on the marriage customs of the Druze in the Shouf Mountains of southeastern Lebanon. Ten Druze informants were selected and classified according to sex, age, marital status and religious status (sheik/sheika). A detailed questionnaire was designed to use during the interviews with these informants. However, after two interviews, it became apparent that a variable questionnaire was necessary to take advantage of the new, richly-detailed, cultural information that emerged with each informant. New questions were developed, in the field, to reflect and gather this new ethnographic data on Druze marriage customs. After examining the case studies of each of the ten informants interviewed for this study, it became evident that certain traditional features of Druze life have withstood a self-imposed isolation and an often volatile history. These key features endure though the social dynamics of Druze life in the shouf is changing. They still tend to marry within their home village, still prefer cousin marriage, but in any case, they will certainly, with rare exceptions, marry within their own religion. The Druze marriage customs can be divided, using informants' own words, into fourteen stages that illustrate the basic structure of Druze marriage. However, certain situational 
variants exist. These variations reflect the way their marriage customs adjust to the demands that emigration and a civil war have placed on their social system.

Changes have occurred in the basic patterns of the Druze marriage in three areas. Today, young men and women are allowed more of a voice in selecting their spouses. The second area is in the determination of the advance and delayed brideprice. Traditionally, the fathers of the bride and groom decided all financial matters, but today the couple is allowed to participate more in the decisionmaking process. The third area of change has been in choosing the residence of the couple after marriage. The groom's, father's house has been the traditional home of the couple, but the preferred type is increasingly that of neolocal residence.

The role of marriage, in contemporary Druze society, occupies a position of importance and cannot be studied independently of the entire social order. Marriage works to preserve their ethnicity, promotes societal solidarity, and provides legitimacy for Druze children. Marriage, among the Druze today, acts as a balancing mechanism in accommodating to the inevitable changes that are occurring due to modernization and the devastating civil war in Lebanon. 
SOMETHING OLD, SOMETHING NEW:

MARRIAGE CUSTOMS AMONG THE DRUZE

IN THE SHOUF MOUNTAINS OF LEBANON

by

NANCY SCARLETTE BEAINI

A thesis submitted in partial fulfillment of the requirements for the degree of

\author{
MASTER OF ARTS \\ in \\ ANTHROPOLOGY
}

Portland State University 
TO THE OFFICE OF GRADUATE STUDIES:

The members of the Committee approve the thesis of Nancy Scarlette Beaini presented May 2, 1989.

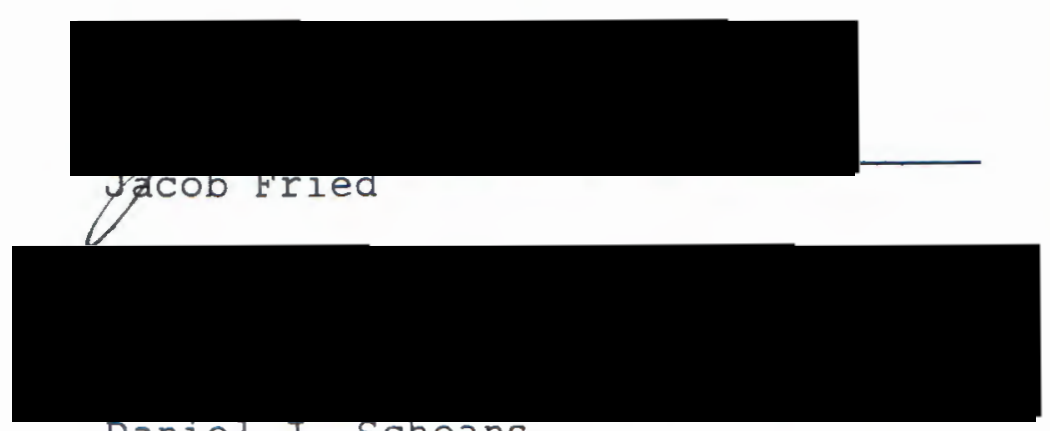

Daniel J. Scheans

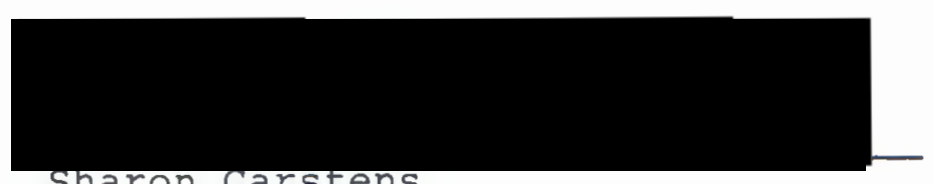

Sharon carstens

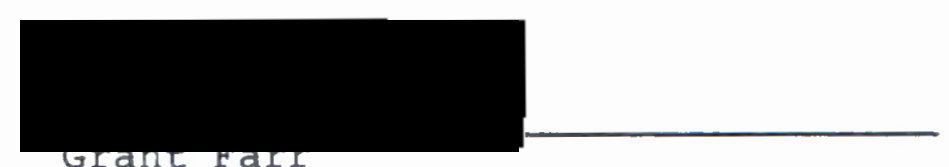

Grant rar

\section{APPROVED:}

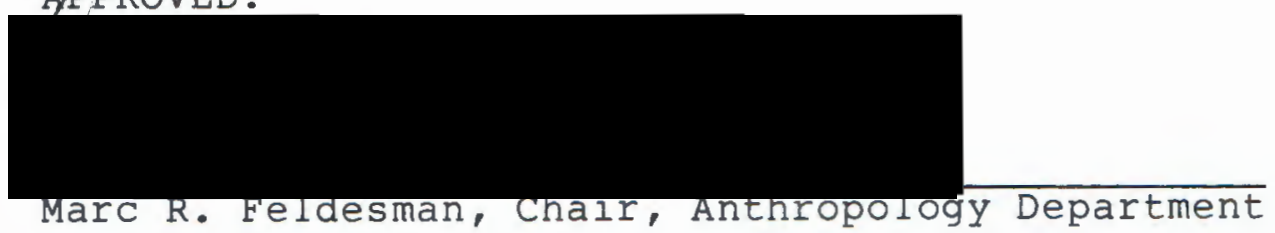

C. William Savery, Interim Vice Povost for Graduate Studies and Research 


\section{ACKNOWLEDGMENTS}

I want to say thank you to my mother and father for teaching me the value of knowledge, a love of learning and persistence in achieving my goals. I want to say thank you to my husband, Samir, without whom this thesis would not have been written. You inspired me to begin this study of your people, spent long hours explaining your culture and Druze marriage to me and encouraged me as a I wrote. I want to tell my children, Nisan and Noura, how much I appreciate their hours of drawing, storybook tapes and amusing each other while "Mama works on her computer"! My friend, Barbara, deserves a special note of thanks for all of the words of comfort, sharing of frustrations, and late night discussions on culture and the relative merits of putting ourselves through this ordeal! Sincere recognition and thanks must also go to Professors Jack Fried and Dan Scheans for their unfailing advice, moral support, forbearance, and high academic and professional standards. You both pushed and inspired me to do my best and yet realize I can always do better. Lastly, I want to extend my heartfelt gratitude to the Druze men and women who opened their homes and hearts to me and who were so generous with their time, patience and interest in my research. Enshallah, I will have the 
opportunity to do more research among you in the shouf, in a peaceful Lebanon. 
TABLE OF CONTENTS

PAGE

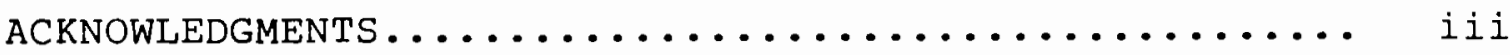

LIST OF FIGURES....................... viii

CHAPTER

I INTRODUCTION.................... 1

Research objective.............. 3

Brief Historical/Social Description:

Druze in the Middle East...........

4

The Druze Religion

Druze Social Organization

I I WHAT NEW DATA IS NEEDED? ..........

Survey of Druze Marriage in the

Ethnographic Literature.......... 14

Review of the Key Literature......... 15

General Overview of Druze Marriage

customs.................... 18

What New Data is Needed?........... 22

II RESEARCH METHODS EMPLOYED FOR THIS STUDY.. 24

Method One: Participant-Observation... 24

Method Two: Questionnaire/Personal

Interviews................. 25

Brief Biographical Sketch of Druze

Informants................. 26

Khattar Family 
Riman Family

Separate Men

Additional Notes

Marriages Between Informants

Miscellaneous Marriages in Both

Families

Non-Druze Spouses

Suggested Pattern for Druze Kinship....

IV AN ETHNOGRAPHIC DESCRIPTION OF DRUZE

MARRIAGE IN THE SHOUF MOUNTAINS OF

LEBANON

Historical Descriptions of Druze

Marriage Customs...............

The Cultural Framework of a Modern

Druze Wedding.................

1. Parents Decide Their Son is Ready to Marry

2. Visiting the Young Woman and Her Family to Consider Marriage

3. Man and His Family Agree on Which Girl to Propose To

4. Formal Proposal of Marriage Acceptance or Rejection

5. Mahr is Negotiated and Marriage Contract is Drafted

6. Payment of the Advance Mahr

7. Hatou El-Khutbi - Forma Exchange of the Rings

8. Khas Al-Jehaz - Preparation of the Bride's New Clothes

9. Katabet Elekteb - Signing the Marriage Contract

10. Elekteb Maktoob - Legally Married

11. Sandit Al-Arous - Displaying of the Bride

12. Naklet Al-Arous - Transfer of the Bride

13. Urs - Wedding Celebration at the Home of Groom's Parents

14. Beit Al-Arees - Home of the Groom 
vii

CHAPTER

PAGE

V

CONCLUSIONS.

107

Closing Remarks.

SELECTED REFERENCES. 110

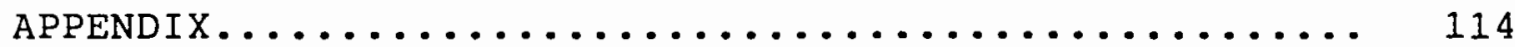




\section{IIST OF FIGURES}

F IGURE

PAGE

1. Geneological Chart of Druze

Informants and Their Families...........

2. Diagram of Cousin Marriage Among the

Druze.......................... 
CHAPTER I

\section{INTRODUCTION}

Very little ethnographic research has been done on an ethnic minority in the Middle East called the Druze. One possible reason for this lack of information may be due to the Druze themselves. Since the 11th C., they have evolved as a secretive and distinct community within their own geographical niche. The Druze are a closed religious and social sect that have managed to remain autonomous and yet blend into the age-old, communal fabric of the Middle East. Historians, anthropologists and theologians alike consider the Druze to be unique in that cultural milieu. Therefore, details of their past and present religious beliefs and social organization, including marriage customs, have continued to be veiled in mystery. Dating from as early as the 12 th C., countless travelers have written fascinating, but often inaccurate portrayals of the Druze. These narratives have only served to perpetuate numerous misconceptions about their social practices and cultural traditions.

Within each culture there are traditions and practices that are specific for that particular geographical setting. Yet, there are also common threads that run through all 
cultures. One of these is the nearly universal presence of marriage, which is a major component of human social organization. For most societies, marriage entails the formation of alliances, the reciprocal exchange of brides and resources, and the transmission of social and economic status and privileges. These spheres of influence, most often, encompass the extended families of both the bride and groom. Ethnographic evidence from many cultures show that the bonds formed through the institution of marriage create expectations and obligations on many levels.

Because of the importance of male-female relations in any society, institutions have evolved that establish and maintain these relations. Marriage has emerged as a method of control, for the human social system, of the forceful, and often volatile, instincts of sexual attraction. Marriage is viewed, by many cultures, as a means of regulating women and children as human resources and to provide for their economic well-being. This researcher suggests that a reasonable working definition of marriage can be illustrated by Howard, as seen below:

...a socially sanctioned sexual and economic union between men and women... Marriage is also the most common way of ensuring that the child and its caretaker are supported.... it seeks to solve sexual competition... it is encouraged by sexual division of labor... (Howard 1986:214-215)

Some quantitative studies have been done on Druze marriages, notably the well-researched book by Alamuddin and Starr (1980). Books have also been written on the Druze and 
their overall history and culture. Most recently, Robert Brenton Betts (1988) has published a book which is an accurate and much-needed, general synthesis on Druze history, political development, traditions and society. Such materials supply the general background to the finegrained ethnographic data on Druze marriage which is the core of this thesis.

\section{RESEARCH OBJECTIVE}

Although marriage is found, in one form or another, in all human societies, constructing a working model of any marriage system requires analyzing its social context. By studying the marriage customs of the Druze, one can gain insights into their social organization, religious tenets, kinship and alliance systems and patterns of reciprocal and exchange behavior.

A descriptive ethnography of marriage customs has not yet been done for any of the Druze who are concentrated in Lebanon, Syria, Jordan and Israel. It would hardly be feasible, in this thesis, to cover such a broad spectrum for all the Druze living in these countries. Therefore, the scope of Druze marriages has been narrowed to an investigation of only the marriage customs and traditions of the Druze living in the Shouf Mountains of southeastern Lebanon. A substantive ethnography that investigates Druze 
marriage practices is needed in the slowly-growing body of literature on Druze culture.

It is the wish of this researcher to document presentday Druze marriage customs and their age-old traditions before the civil war in Lebanon forces irreversible, cultural changes on the Druze.

In order to achieve this objective, the aim of this thesis is to provide detailed, ethnographic data on current Druze marriage customs in the Shouf Mountains of Lebanon.

\section{BRIEF HISTORICAL/SOCIAL DESCRIPTION:} DRUZE IN THE MIDDLE EAST

A brief history of the Druze sect is necessary in order to familiarize the reader with the socio/cultural setting that this research stems from.

The Druze have had a long, often turbulent history of self-imposed isolation within the varied cultural backdrop of the Middle East. Today, they continue to be an ethnic minority, however the Druze hold a restricted and yet dynamic position in the fabric of their social and political arena. Due to the political turmoil in the Middle East today, it is difficult to get precise demographic figures on the Druze. The census figures cited in the literature vary considerably. The most reasonable estimate is that made by Robert Brenton Betts. He writes that the Druze "...today number some nine hundred thousand Arabic-speaking citizens of Lebanon, Syria, Israel and Jordan, scattered in towns and 
villages...". (Betts 1988:3) Historically, the oldest and largest concentration of Druze has been in Lebanon. However, due to the disruptive civil war of the last 15 years, many Druze have emigrated to other countries of the Middle East and to the United States and Canada. In Lebanon, the majority of Druze living in Beirut have moved back to their traditional enclave in the Shouf Mountains of southeastern Lebanon.

The Druze Religion

An examination of its history, shows that the Druze religious movement began within the overall framework of Islam. However, it is a curious mix of "...Christianity, Zoroastrianism, Judaism and Islam along with a dose of Hellenistic philosophy and Buddhist mysticism." (Abraham $1981: 14)$

The Druze refer to themselves as Muwahhidun ${ }^{1}$ or unitarians. The tenets of the religion are allegorical and esoteric. They believe in the oneness or unity of God, and are absolute monotheists. Makarem (1974) states the following:

All that we can say of God is that He is Existence in its very reality. All existing beings derive

${ }^{1}$ The Arabic words and phrases used throughout this thesis are not classical Arabic. They are the colloquial terms used by the Druze in the Shouf Mountains of Lebanon. The phonetic spelling, in English, for each word or phrase has been carefully selected so that it reflects the Arabic pronounciation as accurately as possible. 
their existence from Him... He is the one, but without being numerical...the one who is God, the divine Unity, is infinite and unlimited and perfect. (Makarem 1974:42)

This belief in the 'unity of being' is called Tawhid. Traditionally, within the 'uggal, (the initiated), the Tawhid is passed down by word of mouth and memorization of the secret Kutub al-Hekmeh, (Books of Wisdom). The 'uggal are most often comprised of men, but women are also accepted. The goal of the 'uggal, both men and women, is to study the more obscure, esoteric aspects of their religion. The juhhal, (non-initiated), are instructed from youth on basic religious beliefs but often remain ignorant all their lives of the deeper, allegorical doctrine of their religion. No new members have been officially admitted to the Druze religion since the closing of the Call in $1043 \mathrm{~A}$. D. The Druze maintain that the number of all the souls on Earth, believers and non-believers, was fixed by God at the time of the creation. This tenet is still subscribed to today. A Druze believes that when he or she dies, the soul instantly goes into the body of another Druze being born. This system is called metempsychosis. Reincarnation, or tagammus, is a strong belief within the Druze religion. There are many recorded accounts of children telling their parents about people and places they know from a past life. Makarem (1974) gives a clear explanation of these beliefs in his book. 
The belief in reincarnation is one of the most important beliefs on which the doctrine of Tawhid is based. Without this belief, the whole idea of man's evolution as conceived by the Muwahhidun, would be invalid. The true knowledge of the unity of God...can only be achieved through man's gradual and continuous experience... One life span is obviously not enough for an individual to realize the real purpose of life. (Makarem 1974:57)

Informants related to the author that "...you must be born a Druze, and you will always die a Druze." (Personal communication to author) Because this religion's theology is secret, even from its own general populace, it imbues its members with feelings of exclusive community separateness. This obscure religion serves as a method of reinforcing and maintaining age-old, cultural traditions.

As will be illustrated throughout the ethnographic data in Chapter Four, the Druze religious ideology of separateness and exclusiveness play a pivotal role in their marriage laws. Traditionally, the Druze have not been allowed to marry outside of their own faith. In recent years, however, records identify a few such marriages, but they have been Druze men married to non-Druze women. A Lebanese Druze woman would rarely, if ever, be allowed to marry a non-Druze man. All of the informants indicated they had never heard of a Druze woman, in Lebanon, marrying a non-Druze man. Although it appears that men have more freedom in choosing a bride, children born to a mixed marriage are not considered to be Druze. If the family is living in a Druze community, it can become extremely 
children are generally ostracized and not recognized as being the offspring of a legal marriage. One informant, Hdiye, said her younger brother, Farid, married a christian woman in the mid-1940's. Their family immediately severed ties with Farid and his new wife. Family members eventually communicated with him, but it took many years before they were willing to accept Farid's marriage.

\section{Druze Social Organization}

The ethnic origins of the Druze are obscure, but it is rumored that the Druze of Lebanon regard themselves as descendants of the ancient Phonecians. Hitti refers to them as a mix of Persian and Kurdish elements. (Hitti 1928) Today, two of the most prominent Druze families, the Jumblatts and Arslans, are thought to be of recent Kurdish origin. These families began to show up, among the Druze, in 17 th $\mathrm{C}$. Lebanese and Syrian politics. Because of their increasing influence in the area, the Jumblatts received the Shouf Mountains as their fiefdom and were eventually accepted as Druze. Today, this family still retains its forceful influence in the Shouf Mountains and plays a key role in all phases of Druze social, economic, political and cultural life.

The gradual recognition, by the Lebanese Druze, of these two politically influential families would seem to indicate a socio-religious flexibility within their culture that is not always apparent to an outsider. It appears that 
this flexibility can, when necessary, transcend tradition and religious dogma.

Today, there continues to be resistance to marrying a non-Druze woman, but it seems that there are individual cases of non-Druze spouses being unofficially accepted by the Druze community. The present Druze leader, Walid Jumblatt has twice married non-Druze women. His mother was half-Circassian and her mother was born in Russian Circassia. (Betts 1988) These women have been tolerated socially but have not, and never can, become members of the Druze religion. One must be born a Druze.

The social organization of the Druze throughout the Middle East has been shaped by many factors; chief among them are geography, politics and religious persecution. One Druze scholar, quoted below, gives her view of the forces that shaped Druze social organization and culture.

Religion is the primary bond among its members...the cause that brought the community into being and the force that has sustained it throughout its existence. (Abu-Izzeddin 1984:221)

During the 11 th $\mathrm{C}$. , the Druze developed as a social unit from the earliest times in the mountainous areas of Lebanon and Syria, where they established tightly-knit, secretive, highly-coordinated, feudal states of peasant farmers. Their leaders were warlord chieftains. (Salibi 1977) Today, due to the Lebanese civil war, the Druze of the Shouf Mountains are organized in much the same manner. The majority of Druze, who in the past, lived in Beirut have now moved back 
Druze, who in the past, lived in Beirut have now moved back to their ancestral villages in the shouf. Walid Jumblatt, often referred to in the press as a Druze warlord, is their political party leader and unofficial head of state. The Druze militia controls all access into and out of the shouf so that the Druze in the Shouf Mountains are organized like a feudal state of the 17 th or 18 th $\mathrm{C}$.

Two powerful conquerors of Lebanon and Syria, the Mamluks of the 14 th $\mathrm{C} .$, and the Ottoman Turks in the early 16th C., allowed the Druze to keep their internal, political autonomy and social structure. Despite these privileges, approval by these dominant overlords was necessary for the Druze dynastic, power-based families to maintain authority within their distinctive feudal traditions. However, this policy of political, religious and social tolerance was not extended to all of the various Christian and Moslem splinter groups present in Lebanon during the Mamluk and Ottoman eras.

In the beginning of the 11th C., al-Darazi, a key missionary during the Druze religion's formative years, followed the Isma'ilite custom, and organized the new Druze converts into a secret sect. The men and women who were initiated into the inscrutable mysteries of the new religion were called 'ugqal (wise/wisdom). These spiritual elite led the general populace, or juhhal (the ignorant). "The juhhal...possess qualities opposed to those of the 'uqqal, 
self restraint." (Abu-Izzeddin 1984:223) Because of the political climate of the 11 th $\mathrm{C}$. , and the ensuing religious persecution, the Druze were taught to hide their religion when faced with a hostile environment. They were instructed to recognize each other by using secret signs, and were encouraged to blend in with their surroundings for personal protection and to ensure the survival of their fledgling religion. This policy of conforming to one's dominant political environment is called taqiyya. A Druze, man or woman, is permitted, in times of extreme danger, to outwardly deny his/her faith and appear to adopt the prevailing religion or social pattern that threatens the family and/or community. A Druze believes in strict honesty with one another, and absolute secrecy concerning religious matters in dealings with a non-Druze. Among the Seven Duties set out by Hamza al-Ali, a principal organizer and revered leader of the Druze religion in the 11th $\mathrm{C}$. , the third pillar of Islam, interpreted by the Druze, is to "...protect divine knowledge from those who do not deserve it and do not withhold it from those who are deserving." (Makarem 1974:100)

In Lebanon today, Druze society is still divided into these two socio/religious classes of luggal and juhhal. The tenets of this religion designate specific behavioral rules and moral values to govern their lives from birth to death. In the Shouf Mountains the juhhal comprise the larger 
segment of the population. The juhhal and the Luggal value the same moral code, commitment to marriage and family, and preservation of their culture. Although, there is a stricter behavioral code for the 'ugqal, such as the prescription against smoking and alcohol, and the requirement of strict sexual modesty, the key difference between the two groups is the amount of time the 'uggal devote to the study of their religion.

To this day, the Druze have retained their autonomy as a socio-religious, political unit, fiercely independent and maintaining customs and traditions that are distinctly their own. In modern Lebanon, since 1943, they have managed their own internal affairs and have a Druze court which handles all domestic disputes, registers births, marriages, divorces, deaths, etc. The same policy exists in syria. In Israel, and on the West Bank, although they have had lands taken away, the Druze are allowed their own civil courts with much of the same control over internal community affairs that the Druze of Lebanon and Syria enjoy. The Druze also have their own Educational Committee, in Israel, which mediates the educational concerns of their scattered communities. Because of their present status as citizens in the Jewish state (not including the West Bank), their position is somewhat different from other neighboring Arab communities. Due to the traditional Druze policy of allegiance to a dominant power, Israel has allowed the Druze 
to serve in the Israeli Army; the only Arab minority it trusts.

A second opinion of how the Druze view their own social organization is summed up rather well by Lebanese politican and intellectual Kamal Joumblatt, the father of the present Druze leader, in the Shouf Mountains, Walid Jumblatt.

Rather than religion, it is our social relations, our mores and our culture which link us to one another and distinguish us from the non-Druses. This shared sense of community and morality has more in common with nationalism and a rather vague sense of nationhood than with religious sectarianism. (Joumblatt 1982:36) 
CHAPTER I I

WHAT NEW DATA IS NEEDED?

SURVEY OF DRUZE MARRIAGE IN THE ETHNOGRAPHIC LITERATURE

Detailed historical accounts of the traditions and customs of Druze marriages date back to the middle of the 19th C. However, the Druze have been mentioned in the written descriptions of many travelers and armchair anthropologists starting with the Spanish Jew, Rabbi Benjamin of Tudela in the 12 th $\mathrm{C}$., who journeyed near Druze territory in Lebanon at the time of the crusades. The Rabbi wrote that they were an incestuous people who allowed fathers and daughters to live together as husband and wife. He also related a story he heard about a Druze festival that was held once a year where men and women engaged in promiscuous sexual relations. This dubious account of Druze behavior can be found in the literature along with the reasonably accurate reporting of personally-witnessed events by Chasseaud (1855), Tweedie (1870) and Seabrook (1927). These authors' descriptions of historical Druze weddings will be analyzed in Chapter IV. 
REVIEW OF THE KEY LITERATURE

In reviewing the available ethnographic literature, it has become apparent that there are five basic references that represent the most comprehensive collection, in English, on Druze culture and marriage practices. These are Alamuddin and Starr (1980), Betts (1988), Hitti (1928), Layish (1982) and Makarem (1974).

The authors of Crucial Bonds, Alamuddin and Starr, are a Lebanese Druze anthropologist and an American sociologist. In researching marriage records (1931-74) from the Druze religious courts, they concluded that the basic structural characteristics of Druze marriage patterns have changed very little over the last 50 years. Considering the socioeconomic and political changes that Lebanon has gone through since 1930, this is rather remarkable. Although the quantitative analysis of marriage data by Alamuddin and Starr is very useful, they only touch upon such qualitative issues as women's roles or the elaborate negotiations in the marriage process of the Druze.

The most recent addition to the growing database on the Druze in the Middle East is Betts (1988). As a scholar and recognized authority on Middle Eastern history, Betts brings detailed source material in English, Arabic and French to this historical and contemporary survey of the Druze. In addition, he also provides insights into the Druze culture of teh Shouf Mountains of Lebanon through 
his years of personal observations and relationships among the Druze themselves.

Hitti's book (1928) is a recognized classic. Basically a work on Druze history, it also includes early 20 th C. descriptions of Druze social organization. In his book, Hitti has translations of such records as marriage codes and the rules for domestic relations between husband and wife. Unfortunately, the book lacks sufficient ethnographic detail on Druze marriage and gives little analysis of what is presented. Since Hitti gathered his data over 60 years ago, it is obvious that new research needs to be conducted, and comparisons made, regarding Druze marriage customs in the modern Middle East.

Aharon Layish's exhaustive study (1982) examines the domestic decisions taken by the Druze religious courts in Israel and the Golan Heights during two different time periods. The first was from the mid-1950's to the early $1960^{\prime} \mathrm{s}$, and the second period was from the early 1960's to the mid-1970's. Layish researched the legal documents used in the Druze courts to describe and analyze the social, historical, religious and legal patterns of marriage, divorce and inheritance in the Druze family in Israel and the Golan Heights.

Scholars are now attempting to build a body of literature for comparative legal studies in relation to the Moslem world. Layish's book is unique for its careful 
examination of the role of law in the Druze community and its fundamental grounding on their religious dogma. Because Druze women have a more equal status with men under their religious laws than do Moslem women in the Middle East, Layish examines the treatment of Druze women under their own laws. Layish's study is useful for this thesis because the religious laws regarding marriage are the same in Israel as they are in Lebanon, syria and Jordan. Therefore, the legal decisions made by the Druze courts in Israel can be studied for patterns with regard to marriage laws in Lebanon.

Makarem (1974) serves as a key resource on Druze culture because of his authoritative presentation of Druze religion. The Druze themselves see their culture, traditions and religion as intertwined. Makarem is, himself, a Lebanese Druze, and his research was approved by the leader of their religious and social community, the Sheik al-Akkel. The value of his work lies in his explanation of the allegorical tenets of this religion and the role they play in Druze social organization and marital traditions.

Finally, a sixth reference has been selected, although it is not considered to be a primary source for this thesis. However, Murphy and Kasdan's (1959) seminal article discusses the structure of parallel cousin marriage and how it relates to other forms of Middle Eastern marriages. 
Murphy and Kasdan's insights are essential in perceiving the underlying structure in Middle Eastern marriage rules.

\section{GENERAL OVERVIEW OF DRUZE MARRIAGE CUSTOMS}

Since the inception of their religion, the Druze have been a strictly monogamous sect. Marriage is taken as a serious and sacred responsibility. Makarem writes about relations between a husband and wife as defined in the Law of Domestic Relations in the Druze religion. Their behavior toward each other should be one of "equality and justice". (Makarem 1974:130) Makarem further states that, according to the Law, it is the woman's obligation to obey her husband, but only if he treats her with respect and is fair and reasonable with his requests. A wife's behavior should be in accordance with her husband's wishes, but this does not imply that she is to be submissive to him. That is to say, his wishes should not challenge or suppress her just rights under the Law. In a marriage, the husband is also allowed the same consideration and treatment as the wife. He has a responsibility to provide a home for his wife and any children they may have, and can expect his wife to follow and support him in their life together. These marital obligations and expectations for a husband and wife are to operate without being detrimental to either one's rights as a valued person. The Druze religion states that 
"polygamy is logically contradictory to a life of justice and equality." (Makarem 1974:132)

The Druze are also, with few exceptions, endogamous within their religion. As stated previously, the Druze believe that one will be born a Druze and die a Druze throughout all of his or her reincarnations on Earth. To marry outside of the religion means that any resulting children will not be considered Druze. A person cannot become Druze through marriage or by renouncing their own faith. Druze also prefer endogamous marriages within their own patrilineal kin groups. However, a man may also consider both his patrilateral and matrilateral kin when choosing a bride. According to informants, preference is given first to his father's brother's daughter then father's sister's daughter, mother's brother's daughter and mother's sister's daughter. Their proclivity for familial ties is illustrated in greater detail in Chapter III via Figure 1, the geneological diagram, and its accompanying analysis of Druze kinship. The informants' own words are used in the ethnographic data in Chapter IV to elaborate on Druze kinship patterns regarding marriage partners. The next search level would be their own village, and if no bride is available there, the man's family will seek a bride in a neighboring village. Again, even in other villages, the family connection, if any exist, will almost always be the primary consideration. One informant related that families 
are always linked among the Druze. "It is like silsle (a chain). Families are all tied together. Everyone with the same family name is considered to be related; the same family." (Kamal) A well-known Druze politician and philosopher wrote,

Passing time has not changed our race, for custom forbids the Druses to marry outside their community: there are few exceptions to this rule. (Joumblatt $1982: 36)$

Because of the close-knit, communal ties that bind the Druze together, even men who go to work abroad often come back to their home villages in the shouf Mountains to find their brides. Three of the male informants interviewed for this research are living abroad, and two of them returned to their families to find a wife. These two men also gave evidence of others who follow this pattern with regard to finding a bride. If a man must leave his wife in Lebanon and return abroad alone, he will look for a wife who will be "...compatible with his other relatives...act responsibly in protecting land... and other communal property." (Alamuddin and Starr 1980:94) Evidence shows that in seeking a wife with the above capabilities, the man will almost always look first within his kin group (see preferred order on preceeding page), because "...no one cares for your family like a relative will." (Sleman) If a man does not have an available cousin to marry, he will then consider women living in his village. 
Druze marriage customs recognize kinship and inheritance patterns as being traced through patrilineal descent lines. However, women are allowed, under Druze law, to inherit property from their fathers and husbands. A man may leave a will with provisions to divide his property between his wife and their sons and daughters, however, the bulk of his estate usually goes to his wife and sons. According to informants, a man's wife receives her inheritance and acts as guardian for her sons' share, if they are under the age of about 18 or 20 years old.

An unmarried daughter receives a smaller share of her father's estate because when she marries, her husband and his family will provide for her. By law, if she marries after her father's death, she may take her inheritance with her. If she is married at the time of her father's death, she may also receive an inheritance from him. Whatever property and/or cash a women receives is hers to dispose of as she wishes.

Divorce is allowed within the canons of the Druze religion. Men and women can divorce each other, but they may never remarry the same spouse. In actual fact, the woman is protected by this inability to remarry her spouse, and divorce is not common among the Druze. Informants supported the premise that this law discourages divorce unless it is a very serious matter. This topic will be 
pursued further, with informants' corroboration, in the ethnographic data in Chapter IV.

\section{WHAT NEW DATA IS NEEDED?}

The previous two sections give an overview of the key literature available on Druze culture and marriage and a general statement of their marriage customs. However, there are certain aspects of marriage among the Druze that have not been covered in the published ethnographic literature.

In searching the literature, this author discovered that no detailed, current description of the complete marriage process existed. Alamuddin and Starr (1980) offer a well-researched study of the mahr (brideprice) and Druze marriage contracts, since 1930. But, these are only two aspects of the Druze marriage tradition.

As previously discussed, there are historical accounts of segments of a Druze marriage, explanations of the religion and its role in the marriage process, and information on the Druze and their place in history and politics. By studying Druze marriage customs, one can see how they organize their families and society and how they view their world. Conservative marriage practices help preserve a group's ethnicity, and pass its heritage down to succeeding generations. The Druze still manage to maintain their centuries-old traditions, socio-religious isolation 
and unique marriage practices in spite of the stresses that a devasting civil war imposes on them.

To date, the case study method has not been employed in interviewing Druze informants. This thesis offers data, via this research method, to fill the much needed gaps in the ethnographic literature on Druze marriages. The complete marriage process moves through fourteen stages, and direct statements from Druze informants in the shouf Mountains, are given to illustrate this process.

Chapter III will discuss, in detail, the research methods used to obtain the ethnographic materials for this thesis. 
RESEARCH METHODS EMPLOYED FOR THIS STUDY

Two major research methods were used to obtain data: 1) participant-observation and 2) questionnaires for interviewing Druze informants. Each of these two methods of study will be described, in detail, in two sections of this chapter. A third section will offer a brief biographical sketch of those key informants selected for use in this thesis.

\section{METHOD ONE: PARTICIPANT-OBSERVATION}

This specific culture group, the Druze of the shouf Mountains of Lebanon, was selected for two reasons. This author is married to a Druze from the Shouf Mountains, so there is a personal dimension to this research, but also Middle Eastern cultures have always drawn the attention of this researcher. Because of the bicultural marriage of this author, it was possible to participate in, and observe cultural practices within the close-knit, conservative Druze community in a freer manner than an outsider would be able to do. It was possible to obtain interviews with Druze informants on a more personal level than would have been possible for a total outsider. 
These interviews were conducted during two trips to the Shouf Mountains in 1981 and 1988. One interview was obtained in 1985 when the informant, Nadia, was temporarily residing in the United states. Because this researcher is not fluent in Arabic, an interpreter was used when necessary. Several of the informants spoke English well enough so that the interviews could be conducted in English instead of Arabic. The interpreter chosen was someone who speaks, reads and writes fluent English, so that it was relatively easy to communicate ideas, formulate questions and be introduced to the etiquette of Druze culture. In addition, the Druze interpreter had participated in the negotiations of his sister's mahr (brideprice) and marriage contract and had been a witness to numerous engagement and wedding celebrations.

METHOD TWO: QUESTIONNAIRE/PERSONAL INTERVIEWS

A detailed questionnaire was designed to obtain information from informants about Druze marriage customs. However, it became evident after two interviews that a variable questionnaire was emerging. In each interview, the informant brought new material to the interviewer's attention. There were certain questions that each informant was asked, but it quickly became apparent that the questionnaire needed to be modified in order to take 
advantage of new ethnographic data emerging from each interview.

The ethnographic data that resulted from using this questionnaire can be classified as a sampling of Druze marriage practices from informants. It is not a statistical sample of the Druze population in the Shouf Mountains. This research presents a descriptive contribution to the scanty ethnographic data on Druze marriage practices and traditions.

The following section presents a brief biographical sketch of each of the ten Druze informants interviewed for this study. An example of the questionnaire used in this research is presented in the Appendix.

\section{BRIEF BIOGRAPHICAL SKETCH OF DRUZE INFORMANTS}

In selecting the number and type of informants to interview, there was an attempt to achieve a balanced cross section in terms of sex, age, marital and religious status, despite the small sample used. Considering the state of civil unrest in Lebanon since 1974, there have not been as many opportunities, as this author would prefer to interview a larger number of informants. However, in the author's opinion, the ethnographic data obtained, in spite of the small numbers, is valid, accurate and a contribution to the literature on Druze culture and Middle Eastern marriage customs. 
The main criteria used to select informants were: sex, age, marital status and religious status (sheik or sheika).

As previously stated in Chapter I, the Druze divide themselves into two classes; Luggal (initiated) and juhhal (non-initiated). The 'uggal are comprised of both men and women. A man is called a sheik, and a woman is known as a sheika. Of the ten informants described on the following pages, only one, Sheika Hydiye, is an 'uggal. Her husband, walid, became a sheik about two years before his death, and his father, Najib, memorized all seven books of the Kutub al-Hekmeh (Books of Wisdom) and so became a renowned sheik throughout the Shouf Mountains. Although Mahmood, the second son of Hdiye, was not employed as an informant, it should be noted that the father of Mahmood's wife was also a well-known sheik in Beirut.

Please refer to Figure 1 for a detailed diagram of the genealogy of the following Druze informants and their families. A complete explanation of the geneological information presented in Figure 1 follows this diagram. The reader may refer to Figure 2 for a generalized kinship diagram that includes the Arabic terms for each kind of cousin marriage that is possible among the Druze. 1. Amal - Male, 34 years old. Amal was born in the shouf and left for Europe to complete his high school and college education. He moved to Saudi Arabia to work 
for an international company after graduating from college in 1979. When Amal was approximately 26 years old, he returned to the shouf to find a wife. With the aid of his family and a matchmaker, he met Nadia in 1981 and married her about 18 months later. Amal still works in Saudi Arabia, but he and his family go back to the shouf about twice a year to visit their families. Amal and Nadia have a six-year old daughter and a two-year old son. He is a brother to Kamal, Sleman, Taymoor and Nasrine.

2. Hani - Male, 49 years old. Hani was born in the Shouf and, except for a brief time in Beirut, has lived all of his life there. He works for a foreign pharmaceutical company and is also known as the unofficial public relations man of the Shouf. Hani is called "the man who fixes things". He married his matrilateral first cousin, Nabiha, and they have three children, two sons 17 and 15 and a daughter aged 12 . Hani's brother, Osama, is married to Nabiha's sister, Dalal, and his mother, Arjewan, is the patrilateral second cousin of Hdiye's husband, Walid. Their fathers were ibn ami, patrilateral first cousins.

3. Hdiye - Female, in her early 60's. Hdiye was born and raised in the shouf. She has been a widow since 1982 after approximately 35 years of marriage, and is the mother of seven children. Five of her six sons, and 
her only daughter, are married and have ten children between them. Hdiye does not read or write because she was raised in an era when it was believed unnecessary to educate women. Since her husband's death, she has pursued her studies, to become a sheika, with Druze religious leaders in her village. Hdiye's youngest brother is married to, but currently separated from, his non-Druze wife.

4. Kamal - Male, 39 years old. Kamal was born and raised in the Shouf Mountains. At the age of 20, Kamal left the Shouf to pursue a college education in Europe. He has continued to live and work abroad but returns home often. Kamal is married to a non-Druze woman, and they have two children, a six-year old son and a twoyear old daughter. He is the oldest child and son of Hdiye and his siblings are Amal, Sleman, Taymoor and Nasrine.

5. Nabiha - Female, 40 years old and wife of Hani. Nabiha was born and raised in the shouf. She is a housewife and the mother of three children, two sons 17 and 15 and a daughter who is 12 . Nabiha has lived all of her life in the Shouf Mountains, with the exception of a brief period in Beirut, when Hani took her there after they were married. Nabiha was 22 years old when she married Hani, and they are 
matrilateral first cousins. Nabiha's sister, Dalal, is married to Hani's brother, Osama.

6. Nadia - Female, 27 years old and wife of Amal. Nadia was born and raised in the shouf. She is a housewife and the mother of two children, a daughter who is six years old and a son who is two years old. Nadia lived in the shouf until she married Amal in 1982 and went to live with him in Saudi Arabia. She has also lived in the United States for two years because Amal's company transferred them here. Nadia frequently travels, sometimes without her husband, to visit her family and in-laws. In her family, there are four children with three sons and Nadia being the only daughter and youngest child. Her brother, Jamal, is married to the daughter of Hdiye's brother's son, Karim. To Hdiye, Jamal's wife is bint ibn khale.

7. Nasrine - Female, 26 years old. Nasrine was born and raised in the Shouf Mountains. She was married at 17 , after completing high school, to a man from her village. Arej is ten years her senior and from a family of three sons and two daughters. His father owns several plots of good farming land in the valley below their village and is considered to be financially well off. Arej and his older brother are both in the Lebanese Army and are currently stationed in the shouf. Nasrine is a housewife and the mother 
of four daughters ranging in age from seven years to eight months. She is the youngest child and only daughter of Hdiye. Nasrine's older brothers are Kamal, Amal, Sleman and Taymoor.

8. Noor - Female, 21 years old and wife of Sleman. Noor was born and raised in the shouf. She is a housewife and also helps on Sleman's family farm in the valley below their village. Noor and sleman have an infant daughter born in 1988. They live with Hdiye, Sleman's mother, and just down the road from her parents. Noor speaks a little English which she learned in high school.

9. Sleman - Male, 30 years old. Sleman is married to Noor, and they have a two-month old daughter. He is the fifth son of Hdiye and the son who inherited the family farm when his father passed away in 1982. sleman continues to live with his widowed mother and take care of the land, however, he discusses the farm's management with all of his brothers. Just before he married, he completed a new house, with financial help from his brothers, just outside of their village. Sleman married Noor in 1987 and moved her in with his mother. Sleman has traveled twice to Europe, but did not complete his college education outside of the shouf as four of his brothers have 
done. Sleman is the brother of Kamal, Amal, Taymoor and Nasrine.

10. Taymoor - Male, 28 years old. Taymoor is the youngest son of Hdiye and engaged to marry Lateefi, a second cousin, who is his mother's brother's son's daughter or bint ibn khale. He left Lebanon for Europe when he was 12 years old, joining his oldest brother, Kamal, where he went to high school and college. Taymoor has been working in Saudi Arabia since 1982, but has been back home frequently since 1984. At the time of his interview, he has completed katabet elekteb, or the formalizing of the marriage contract and recording of the mahr (brideprice).

Standard Notations Used to Designate Kinship Relationship

$\begin{array}{lll}F=\text { Father } & Z=\text { Sister } & C=\text { Child } \\ M=\text { Mother } & S=\text { Son } & H=\text { Husband } \\ B=\text { Brother } & D=\text { Daughter } & W=\text { Wife }\end{array}$

Additional People Listed in Text

Khattär Family

$N j=$ Sheik Najib/F of Walid

$\mathrm{W}=$ Sheik Walid/deceased $\mathrm{H}$ of Hdiye (\#1)

$M=$ Mahmood/second $S$ of Hdiye and Walid

$B=$ Bassam/B of Walid and Nabil

$\mathrm{N}=$ Nabil/B of Walid and Bassam (matchmaker)

$A b=A b e e r / D$ of Nabil and Huda 


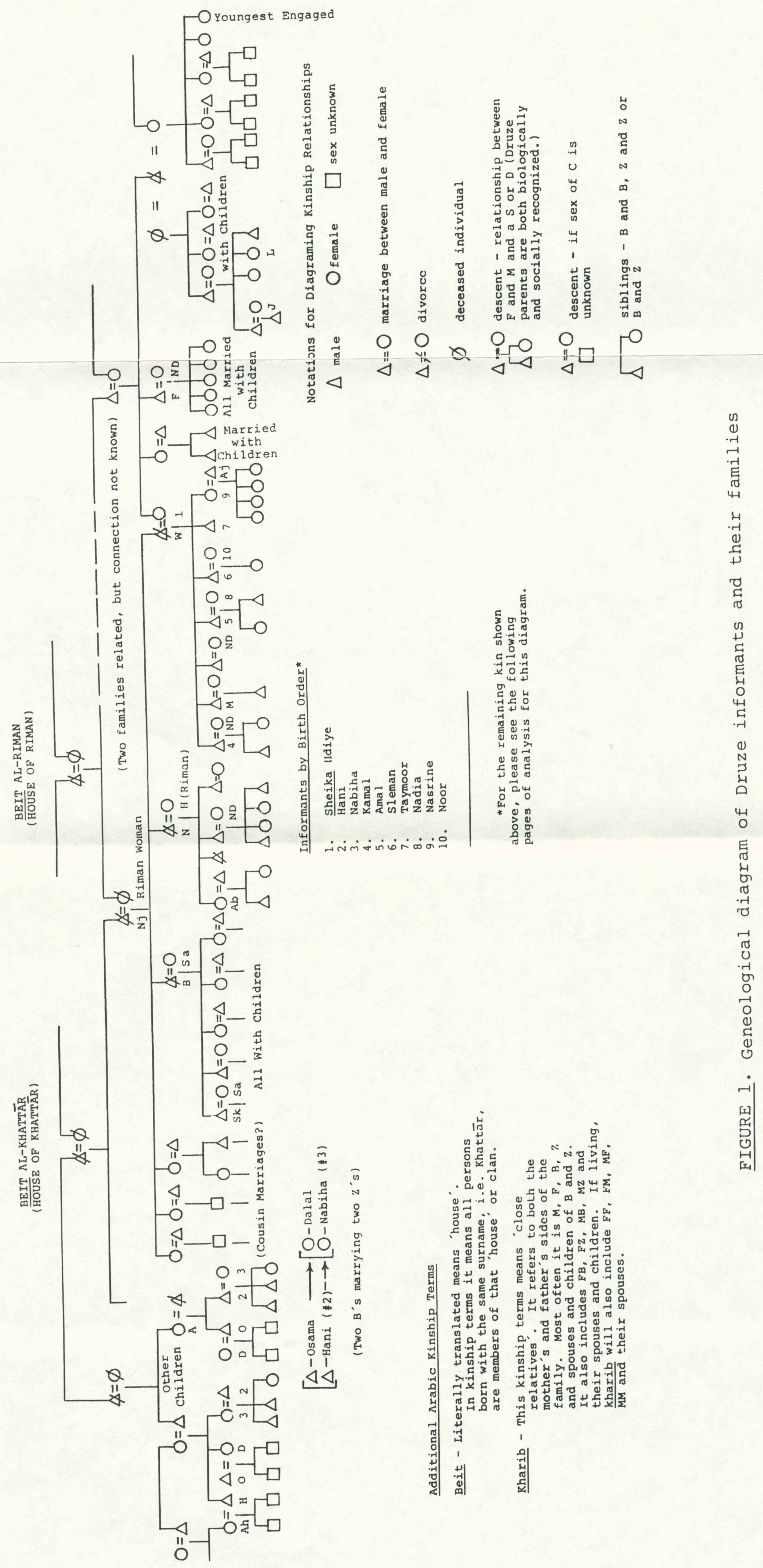


$A=A r j e w a n / M$ of Hani (\#2) and Osama, patrilateral second cousin of Walid (F's of Arjewan and Walid were patrilateral first cousins)

$0=$ Osama/B of Hani and $S$ of Arjewan, married to Dalal who is $Z$ of Nabiha (\#3)

$\mathrm{D}=$ Dalal/Z of Nabiha and $\mathrm{W}$ of Osama also first cousin to husband and his brother, Hani

$\mathrm{H}=$ Hussein/B to Nabiha and Dalal

$A h=A h l e m / W$ to Hussein and was his first cousin

$\underline{\text { Riman Family }}$

$F=$ Farid/youngest $B$ of Hdiye (\#1)

$\mathrm{Km}=\mathrm{Karim} / \mathrm{BS}$ to Hdiye and $\mathrm{F}$ of Lateefi

$L=$ Lateefi/engaged to Taymoor (\#7) being his bint ibn khale or MBSD

$\mathrm{H}=\mathrm{Huda} / \mathrm{W}$ of Nabil Khattār and distant cousin to husband and Hdiye. M was Moslem and reportedly kidnapped by Huda's $F$ who was a Riman.

\section{Separate Men}

$\mathrm{J}=\mathrm{Jamal} / \mathrm{B}$ of Nadia (\#8)

$A j=$ Arej/H of Nasrine (\#9)

\section{Additional Notes}

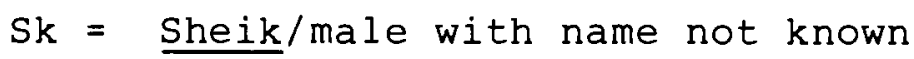

Sa $=$ Sheika/female with name not known

The above sheiks and sheikas make up the portion of Druze society called the 'uggal (the initiated). All of the 
rest of Druze society is called the juhhal (the uninitiated or ignorant).

ND $=$ Non-Druze spouse

\section{Analysis of Figure 1 for Geneology Diagram of Informants and Their Families}

\section{Marriages Between Informants}

Hani and Nabiha

Amal and Nadia

Sleman and Noor

Hdiye and Walid

Kamal and non-Druze

Spouse

Taymoor and Lateefi
Matrilateral cross cousins. She is MBD to her husband, Hani and his brother, Osama. Nabiha is also $z$ to Dalal.

Not related to each other. However, their families knew each other for many years.

Not related to each other. They are from the same village.

Distant cousins. They are related because Hdiye and Walid's M are both from the Riman family. Hdiye is a sheika. Walid became a sheik two years before he died.

He is married to a Christian woman, and they live abroad.

Matrilateral cross cousins. She is MBSD to Taymoor and the daughter of Karim. 
Nasrine and Arej

Not related to each other. They are from the same village and their families have always been close.

\section{Miscellaneous Marriages in Both Families}

Osama and Dalal

Matrilateral cross cousins. Osama and Hani are B's and the sons of Arjewan. Dalal and Nabiha are z's. These two women are khawat silfat or "sisters and sisters-in-law". Dalal is MBD to her husband, Osama and his B, Hani.

Hussein and Ahlem Matrilateral cross cousins. Ahlem is MBD to Hussein. He is B to Nabiha and Dalal.

Bassam and Amalia Not related to each other. They are from the same village.

Son of Bassam and wife Distant cousins. He is a sheik, and she is a sheika.

Daughter of Bassam Patrilateral cross cousins. She is married to her FZS and is a sheika herself.

\section{Non-Druze Spouses}

All four men listed in the geneology who married nonDruze wives, married Christian women. Three of these men live abroad and the fourth youngest $B$ of Hdiye lives in 
Lebanon near the Syrian border. He is separated from his wife, at this writing.

Huda's M (not shown) was a Moslem and reportedly kidnapped by Huda's Druze $F$ in the late 1920's or early $1930^{\prime} \mathrm{s}$.

\section{SUGGESTED PATTERNS FOR DRUZE KINSHIP}

After analyzing the marriage patterns and kinship terms collected from informants, it appears that the Druze can be broadly classified as using a bilateral kinship for affiliation and alliance between families, while continuing to show a definite preference for and emphasis on the patrilineal kin. Both patrilateral and matrilateral kin are respected and sought out for marriage partners, as can be seen in the preceding analysis of the marriages in the Khattār and Riman families.

In reviewing the data from Druze informants, the preference for male kin is clearly evident. Informants stated that when a man or a woman spoke of his/her relatives, father's brothers or Beit Ami (House of FB) were referenced first and mother's brothers or Beit Khale (House of MB) second. "Emphasis is always on the male relatives, your father's brothers or mother's brothers." (Kamal) Beit $\underline{\text { Ami }}$ also refers to $F F$ and $F F B(s)$, if still living, F, S, D and $\mathrm{FB}(\mathrm{s}), \mathrm{FBC}(\mathrm{s})$, and all male and female kin down to and including fourth generation cross and parallel cousins. 
Beit Khale refers to $M F$ and $M F B(s)$, if still living, $M B(s)$, $M B C(s)$ and all male and female kin down to and including fourth generation cross and parallel cousins. Even though Druze women often marry into a separate family line from their natal one, i.e., Hdiye was born a Riman and married a Khattār man, they personally still remain in the descent and affiliation line of their father's family. If the woman marries within the same kin group, i.e., Khattär marrying Khattār, then the bonds of descent and affiliation are doubly strengthened and emphasized.

Descent and inheritance patterns are, exclusively, traced through the male line. Therefore, descent among the Druze is patrilineal, following the classic descent pattern found throughout the varied cultures of the Middle East. 


\section{AN ETHNOGRAPHIC DESCRIPTION OF DRUZE MARRIAGES IN THE SHOUF MOUNTAINS OF LEBANON}

The canons of the Druze faith give very detailed rules for the institution of marriage. Tradition dictates the patterns that are followed and preserved. To a Druze, marriage is a lifetime alliance between individuals and families. Each succeeding generation gives them a familial continuity.

There has been a debilitating civil war in Lebanon since 1974. In spite of the inevitable changes that war brings, the Druze in the shouf continue to value and maintain most of their age-old traditions with regard to marriage.

HISTORICAL DESCRIPTIONS OF DRUZE MARRIAGE CUSTOMS

W. B. Seabrook, writing in 1927, describes a trip he took to Lebanon two years earlier. He and his wife met and stayed with Druze families in the Shouf. While there, Seabrook asked the Druze about a woman's role in their own society, and Druze informants told him that a Druze girl was never permitted to marry a non-Druze man. The girl's father or brothers were honor-bound to find her no matter where she might be and kill her. In the 19 th C. and early 20 th C., 
several authors recounted stories of women killed by male family members because of non-conformity to Druze law.

Seabrook writes that the men of the shouf Mountains, fathers, brothers and even grown sons, had absolute authority and the power of life and death over the women in their families. One of Seabrook's informants, Sheik Fouad Obeyid, explained to him about the Druze views regarding the status of women in their own culture and also told him about the law prohibiting marriage of their women to non-Druze men.

It is for the purity of our race. It is for the good of unborn Druse. Woman is the sacred cup in which our strength and life and honor are handed from generation to generation. If the cup is polluted, it must be broken and thrown away. (Seabrook 1927:227)

Three author/travelers, writing over a span of 70 years, Chasseaud (1855), Tweedie (1870) and Seabrook (1927), all describe witnessing a Druze wedding. Three days before the wedding celebration, the groom rode in a formal procession, with friends from his village, to the bride's home. He and his friends were all well-armed, as was the bride's father and the male members of his household. The father greeted the groom and his entourage at the door of his home.

In the presence of all the village, the final discussion of the marriage contract was held. The mahr (brideprice) was renegotiated, often with the bride's father asking for a little more than originally requested for the 
value of his daughter's hand. It was the groom's father who paid the mahr for his son's new wife.

The girl came out, heavily veiled, with her female relatives. The young man asked her directly if she would marry him. She responded, "Yes." She then presented her future husband with a dagger encased in a woolen scarf she had knitted herself months or even years before. After this public appearance, the newly-engaged girl went into seclusion for three days before her wedding, while the groom remained with his friends as guests of his future father-inlaw. The men spent the three days in celebration of the impending marriage, enjoying music, dancing and abundant food. All three authors said they were told that the dagger was a symbol of the death penalty the bride would face if she was ever unfaithful.

...the symbol of the law by which her husband himself cannot unsheathe the knife unless all her own male relatives are dead, but must return the dagger and the girl to her father or brother who pronounce and execute the sentence. (Seabrook 1927:227)

The dagger also symbolized protection for his future wife because the husband may "...resort to it in order to protect his wife from some murderous assault..." (Chasseaud $1855: 150$ )

Cousin marriage is also described by these three travelers. This was the preferred form of marriage because it perpetuated and strengthened alliances between families. Information from the time period between 1855 and 1927 
indicates the young men generally married at 16 or 18 years old. Families felt that, at this age, their sons were old enough to support a wife. The girls usually married at about 13 or 14 years of age because they were considered women, physically, at this time.

Marriage was a civil contract among the Druze with no accompanying religious ceremonies. Usually a girl married a cousin, who was a man she had at least known as a childhood playmate or had seen at family gatherings. But, if the groom was from another village, it was not uncommon for the bride to meet him, for the first time, at their engagement.

Seabrook, Tweedie and Chasseaud all witnessed and described various stages in a Druze marriage. They all were present at the procession to carry the bride from her home to that of her groom's parents and all attended a wedding celebration.

In 1855, Chasseaud chronicled a Druze wedding procession he witnessed in the shouf. He described the people as "a riotous crew...lighted by numerous torches." (Chasseaud 1855:143) The procession was led by two young men dressed in brightly-colored clothes, who leapt, danced and sang as they marched along, firing off rifles as fast as they could be reloaded.

Following these young men came a band of drums and pipes. A man followed along with a bottle and glass to give them a drink when they got thirsty. After the band came the 
shebbaheen, young men from the groom's village. These 20 to 40 young men sang romantic love songs until they became hoarse from their strained efforts. Next, the elders of the village walked, rather sedately, but also firing off their pistols into the air.

The bride followed next in the procession. She was mounted on a horse and led by two men with torches. Men and women surrounded her horse as they walked beside her. The bride was completely covered in a heavy, white veil, which served to protect her from the immodest looks of the general public. Underneath this veil, she was dressed in fine clothes with fresh flowers and all of the jewelry from her mahr for decoration.

After the bride had passed, three or four men followed on horseback with mules loaded with baggage. These sacks held the bride's additional clothing and jewelry which she took to her new home. Last in the procession were several old women from the surrounding villages who came to enjoy the festivities and excitement.

Chasseaud writes that after the procession had passed, he asked his guide to talk to one of the Druze men and ask him all about the marriage customs of the Druze. He said that his informant was quite willing to talk to them, and told Chasseaud that "...No tie can be more binding or sacred with the Druze than the promise of marriage." (Chasseaud 1855:147) The Druze man described the betrothal of children 
taking place at birth or early childhood, and, due to the respect and obedience these children accorded their parents, they would not rebel against these promises. Chasseaud was told, though, that most young people became engaged when they were old enough to participate, somewhat, in reviewing the choices available. This informant told him that "...young men and maidens have long since secretly formed their respective likes and dislikes." (Chasseaud 1855:148) During the three days before the wedding celebration, the girl retired to her parents' home with her female relatives and friends. For those three days, the bride took ritual baths as a "process of purification". Among the women, there was much crying and sadness because a daughter of the house was leaving. This ritual response was noted by Chasseaud and he wrote that "...upon all occasions, were a proper display of regret and grief is deemed indispensable." (Chasseaud 1855:152)

Chasseaud was invited to attend the wedding celebration at the groom's home for the same bridal procession he had witnessed. He describes in great detail the preparation of the food, the house and the celebration itself. Inhabitants of both the bride's and the groom's village were invited to the groom's home for this celebration. The house itself was reserved for both families and honored guests. The poorer villagers were fed the same food but had to remain in the courtyard of the 
house. Gunfire was heard repeatedly throughout the celebration, as was music, singing and speeches.

The bride, upon entering her new home, was taken immediately to the "nuptial chamber" by the female relatives of the groom. Chasseaud was told that the bride spent her time crying and regretting her lost days of childhood in her parent's home. He was informed that "...amongst her people it would be considered highly indecorous if she did not indulge in a proper amount of lamentations, sighs, and tears." (Chasseaud 1855:165)

Chasseaud was allowed to witness the final stage in the wedding celebration. At midnight, the groom, his male relatives and all the guests proceeded to the nuptial chamber to meet the bride. An older woman took the groom by the hand and led him through the door of the chamber. Chasseaud and his companions, as honored guests, were allowed to stand directly behind the groom at the doorway. He describes the bride standing in the room enveloped in a red veil that was covered with tiny brass stars. On either side stood two of the groom's nearest relatives (not mentioned if they were male or female) and the groom's mother handed him the tantoor (horn), which he placed on the bride's head as he removed her red veil. The bride was then viewed by the assembled crowd at the doorway. All of the women then rushed from the room screaming; the guests were forced to move away from the door, and the door was closed. 
As a final note from Chasseaud, he writes that the Druze told him about their belief in evil spirits.

Gins or evil spirits are usually more than ordinarily busy upon such-like occasions, and they believe that noise and wakefulness will frighten them away from interfering with the future happiness of the newly-wedded pair. (Chasseaud 1855:168)

Fifteen years later, in 1870, Tweedie described a wedding procession that was much the same as the one Chasseaud saw. His account agrees closely with that which Seabrook gives in his 1927 book. Tweedie also gives a description of the red-veiled bride in the nuptial chamber receiving her tantoor, which was a symbol of her new status as a wife. He writes that "When the bridegroom begins to remove the veil, the women rush from the apartment screaming." (Tweedie 1870:56)

This tall horn or cone is described in many chronicles of the 19th C. and early 20 th C. Middle Eastern customs. It is not exclusive to the Druze. This researcher has seen old photographs in Lebanon with this veiled tantoor on women's heads.

In 1925, Seabrook described a bridal procession he witnessed as "noisy and full of color". (Seabrook 1927:230) The procession was led by the walking groom, who had long, braided hair and a white kafiyeh (headdress) over his head. The bride came behind him riding a horse side-saddle. She was completely draped in heavy, white veils from head to foot. Behind her marched the groom's male relatives and 
friends chanting, singing and firing their guns in the air. Behind these young men came the village elders, solemn for the occasion; the women and children brought up the rear of the procession.

THE CULTURAL FRAMEWORK OF A MODERN DRUZE WEDDING

Listed below are fourteen major stages that define a Druze wedding today. These structural patterns are central to a traditional marriage, but as the interviews revealed, they have variations caused by individual circumstances, or the everpresent, often violent, political environment that permeates Lebanon today.

It is important to note that the division of a Druze marriage, into fourteen stages, was not determined by this researcher. The existence of such stages emerged, after detailed questioning, through the interviews obtained from the Druze informants themselves. Each stage, described below, will be discussed in detail with examples and quotes from Druze informants. For a more comprehensive explanation of Druze kinship, and the geneology of these informants, please refer to Figure 1 and its accompanying text. 1. Parents decide their son is ready to marry and choices are made regarding which girls and their families are suitable to visit. The daughters of father's brother(s) and mother's brother(s), of the young man are considered first, with priority given to bint ami 
or father's brother's daughter. A matchmaker may be consulted during this first stage.

2. Informal visits are made, often by the young man's female relatives first, and later, by the son and father too. If a matchmaker is involved, this person may be included also.

3. The choice of girls is narrowed so that the son and his parents may agree on which girl he should propose to.

4. A formal proposal of marriage is made to the girl and her family. Usually, the girl and her parents decide, together, whether to accept or reject this request.

5. Mahr, brideprice, is negotiated. The mahr consists of both advanced and delayed payments. The marriage contract is drafted and agreed upon by both families.

6. A payment of advance mahr is made. Gold jewelry and engagement rings are the primary forms of advance mahr.

7. Hatou el-khutbi: "they have exchanged the rings". This is the formal exchange of engagement rings, traditionally held at the bride's home. Maktoubeen, "they are engaged".

8. Khas al-jehaz: "cutting of the cloth". This entails cutting cloth for the bride's new clothes which she will take to her new home. It also includes preparing lingerie, 1 inens and embroideries. 
9. Katabet elekteb: "writing the book". At this stage, the marriage contract is formalized and signed, and the delayed mahr is also recorded. Witnesses and both families are present.

10. Elekteb maktoob: "the book has been written". The bride and groom are now considered legally married, however circumstances may arise in which they may not be able to live together immediately. The couple will each return to their respective parents' homes to prepare for the wedding celebration, if it is to be the same day as katabet elekteb.

11. Sandit al-arous: "displaying of the bride". This takes place at the bride's parents' home. She is presented to her relatives and friends in her wedding gown and the jewelry from her mahr. She sits on the kerset al-arous, "bride's chair", for all her guests to see and admire.

12. Naklet al-arous: "transfer of the bride". This is the formal transfer of the bride from her parents' home to the protection of her new husband.

13. Urs: "the wedding celebration". Typically, this occurs at the groom's parent's home. It can be the same day as katabet elekteb, or, even months later. A couple is not permitted to live together until after the urs has taken place. 
14. Beit al-arres: "home of the groom". This is the couple's home after the urs. Traditionally, it is the home of the groom's parents.

\section{Parents Decide Their Son is Ready to Marry}

As described in the preceding section, the first stage in the Druze marriage process begins when the boy's mother approaches him about considering marriage.

Most of the Druze have been enculturated to view themselves as members of a family unit, including both their immediate family and their wider circle of kin (refer to Figures 1 and 2 for explanations of Druze kinship and cousin marriage). Children learn that unfailing loyalty and obligation to the family is their way of life.

Remarks about expected and preferred marriages are remembered and incorporated into the perspective of young children...Most children come to participate in discussions of such topics with elder kin well before adolescence and be familiar with the family's general or specific expectations. (Alamuddin and Starr 1980:43)

Within the last 20 years, the age at which young people marry appears to have changed slightly. Today, the Druze legal code specifies the acceptable minimum ages for marriage as 16 for the boy and 15 for the girl. Informants said that to marry without parental permission, the boy and girl must be 18. At this age, the only legal requirements are two witnesses for each at the Druze court. However, almost without exception, the families of both the boy and girl are also present at the marriage ceremony. 

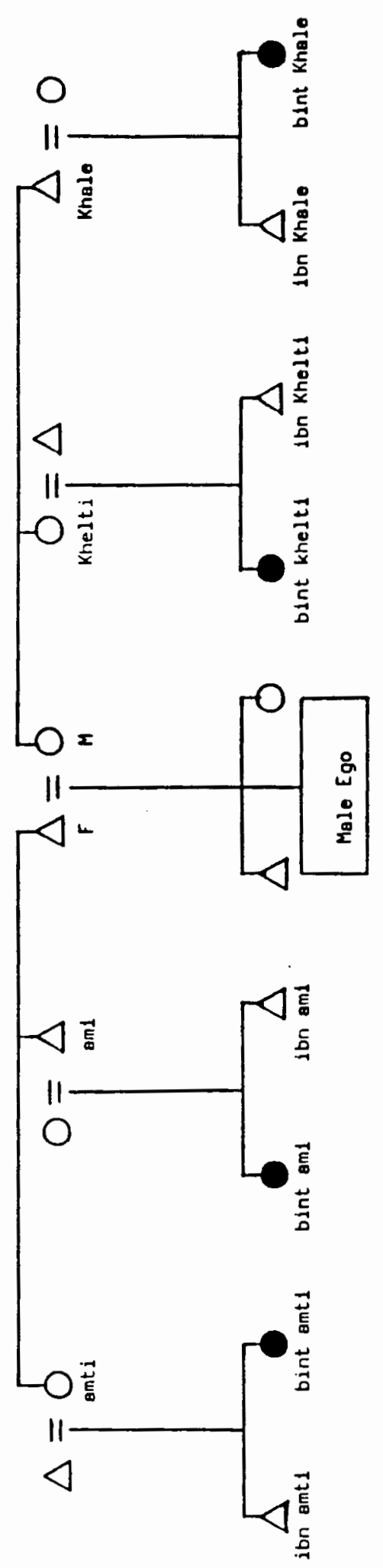
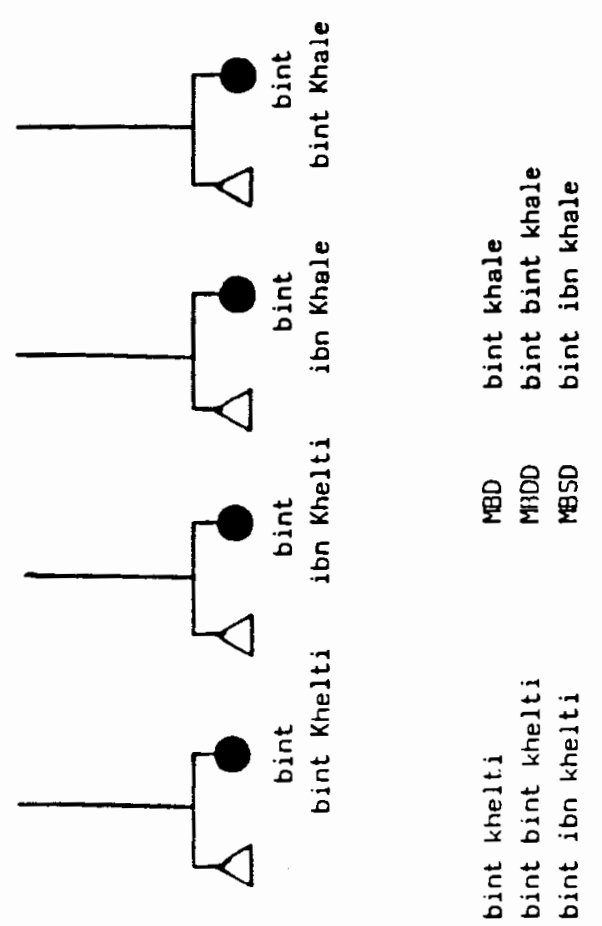

율 울 울

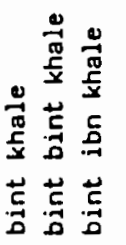

$\stackrel{0}{N}$
$\stackrel{4}{0}$
$\stackrel{0}{\nu}$

品

0
0
0
$0-1$
4
4
0
2
5
5
0
0
0
0

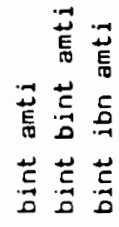

온온온

4

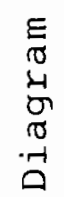

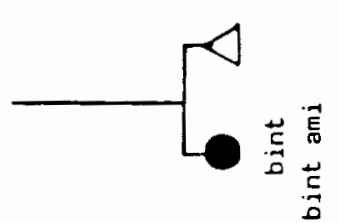

苭 䓂

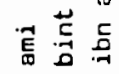

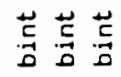

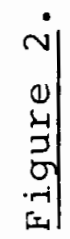


Informants agree that young men are usually in their early to middle $20^{\prime} \mathrm{s}$, and the young women are about 18 years old when they marry. The prospective groom has completed high school; a few have graduated from college. The brides may become engaged at 16 or 17 , but they usually graduate from high school before they marry. Very few of the young women go on to college. Perhaps the reason for the lack of a college education among the young Druze women in the shouf is that they are not often allowed outside the home environment unaccompanied. Traditionally, there is segregation of the sexes in Druze society, however, there are degrees of segregation, depending on whether the woman is married or unmarried. Young girls or unmarried women do not go out alone or even in groups because socializing is always done with family members. Almost without exception, young women live with their natal families until they marry.

In the Druze marriage process, deciding which girls and their families are suitable to visit can be very time consuming for the prospective groom and his family. However, they usually have the help of relatives and friends. The role of female relatives in the Druze marriage process, although more private than public, is vital. Because Druze segregation of married women is not as rigid as in other areas of the Middle East, there is evidence from female informants to show that they often play a key role in the marriage decisionmaking process, both for male relatives of their own families 
and those of their husband's. These male relatives are usually brothers, husband's brothers, brothers' sons and sisters' sons. In addition, this key role certainly extends to selecting a bride for a woman's own son(s).

Because a married woman can more easily inquire about a prospective bride, it allows both families to be diplomatic in discussions of intentions. Both sides can withdraw and still retain their honor because these were only initial inquiries. There are times when a matchmaker will also be consulted. This person may be a man or a woman and is customarily a gregarious member of the community. If a matchmaker is a man, he often relies heavily on his wife to help, unobtrusively, in his search for a bride for a specific young man. Because of the important role that married Druze women often take in assisting families looking for future brides, the matchmaker's wife can actively, yet subtly, make inquiries about a young girl to her family. Generally, a matchmaker is approached indirectly, as will be described in the words of the informants themselves.

If the young man's mother has consulted a matchmaker, she usually will not speak to anyone else until she has given this person a chance to see what girls' families he or she will suggest. It is viewed as an honor to look for a bride for a family's son; therefore, it is a sign of respect that the man's family wait until the matchmaker has had a chance to suggest some possible candidates for their consideration. A 
matchmaker, man or woman, does not receive any money for his/her services. It is with increased social standing in the community that the matchmaker is paid for services rendered. Druze women have traditionally been accorded the status of near equality with men in many areas of their culture. However, "...in the matter of female chastity there can be no compromise." (Betts 1988:42) Several informants, both men and women, said that a man will marry someone who will be a good mother for his children and a woman who will respect his family name. The issue of virginity in a possible bride is of extreme importance to the families of the man and woman. For this reason, a man and woman, with rare exceptions, will not be left alone before they have been formally engaged and have written the marriage contract. Even then, unchaperoned visits are not common, although individual families may allow some contact, for a specific occasion, without a chaperon being present.

If there is more than one son in the family, the brothers frequently marry in an age sequence. Each will marry in turn, as he becomes old enough. The younger son will usually defer to his elder brother in the selection of a bride. If, for some reason, an older son is not ready to marry, his younger brother will ask his older brother(s) if there is a specific girl or family he is considering for marriage. A family is careful to avoid rivalry between brothers for the same girl. 
Several daughters in a family usually means, as with the sons, that they marry in an age sequence. In a village setting, young men and their families know who is next in line, in any given family, for marriage. However, if a younger daughter receives a marriage proposal before an older sister, it will still be given full consideration before accepting or rejecting the young man.

Hereafter, the informants' own explanations will be used to illustrate in detail the first stage in a Druze marriage, schematically presented in the text above. As previously indicated, informants stated that a boy will usually be about 18 years old when his mother first mentions the idea of marriage to him. This age, traditionally, was considered the beginning of manhood, when a young man should be able to support himself. People say he could do maftoofa, "open a house". A young girl was often considered of marriageable age at 14 or 15 .

A mother doesn't wait until her son comes to her to say he's ready to marry. She hints to her son that it is time. She goes to his father to discuss it, and if they agree, she goes back to their son and says, "We'll look for a bride for you." It all starts as a joke. The son refuses, but it helps to build him up. (Kamal)

Very often there is a specific reason why the mother begins to talk to her son about marrying. Hdiye said that she was worried that two of her sons, Taymoor and Mahmood, might marry non-Druze women because she already had two other sons who married Christians. She said that although she loved her 
two foreign daughters-in-law, she did not wish to have any more foreign women brought into her family. This was Hdiye's primary reason for beginning discussions of marriage with Taymoor and Mahmood. She also said that before her husband's family approached her family about her marriage, at age 14, they were afraid that he would marry the wrong girl because he was young and wild at 18. "My husband's mother suggested that they should tie my husband up to a proper family." (Hdiye) Taymoor confirmed that it was his mother's fear that he would marry a non-Druze woman that prompted him to begin thinking of marriage. However, he was also candid when he gave his own reason for considering marriage.

My mother had her mind set on getting me, not married right away, but involved... involved formally... At the same time, I was living in saudi Arabia for two years, and when you live there you think a lot about having a wife. That is what really got me to agree and start thinking about a certain person to propose to. (Taymoor)

Taymoor said that he was 24 years old when he began to consider his mother's suggestion to get married. He had already completed college and was working for an international company in Saudi Arabia when he proposed to Lateefi in 1984. Another informant, Nadia, said that the age, today, for a man to begin looking for a bride is about 24 .

The mother will not encourage her son to start thinking about a bride until she makes sure that he is able to support one. He must secure some kind of a future. So, it is not usually before the age of 24 . (Nadia)

She further states that all three of her older brothers were 
not married until they were in their middle 20's. They had finished their college education abroad and then gone back to the shouf to find brides, with the help of their families.

Nadia also describes the relationship between a girl and her mother with regard to accepting a man for a husband. She says that a girl's family will never be the one to approach a man's family concerning a possible marriage. It is the girl who must sit and wait for the man to come and visit her and her family. But, the girl's mother begins to discuss the process with her daughter that will begin when the girl is about 16 or 17 .

Yes, the first step can be that the mother or family of the man decides that it is time to look for a bride. But, I did not sense anything from my older brothers getting married. I could see my girlfriends in the village getting married. I realized that there were men looking for brides. I knew that my turn would come soon too. It was time for me to marry. When I was 15 or 16 , then there was knocking on the door...Normally, the age is around 16 or 17 that people will begin to approach a girl to marry. It is known that a girl is ready physically when she is a woman, at around 15 or 16 ... The mothers begin to warn them about people coming to see the family about the daughter's hands in marriage. (Nadia)

Nasrine, another female informant, stated that mothers introduce their daughters to the idea of marriage when they physically emerge into womanhood. Informants, both male and female said that for most mountain girls, this is around the ages of 16 or 17 . Nasrine was 16 when she met her future husband and negotiations began for her marriage. She was 17 when she married her husband, Arej. 
Hdiye said she was married in 1941 at age 15 . When she was 14, her mother decided it was time for her to get married. She remembered that her mother and legal guardian (her father died when she was two years old) said they would then begin to consider men that came seeking a bride.

As previously discussed, a matchmaker may be indirectly consulted regarding the selection of a bride. Or, as Hdiye reports,

...sometimes the man or woman, the matchmaker comes to you. They know who you are. The villages are small. The people all travel around. They know who everyone is and who is of the age to get married... When my family decided I was ready to marry, the local matchmakers and my relatives on both sides of the family, they knew of my age now. (Hdiye)

In the case of Nadia's brother, Jamal, a matchmaker was directly consulted, but this person was someone that Nadia's parents had known for years. Nadia's mother and this man's wife were very good Eriends, and both families had summer homes next to each other. Nadia refers to this man as Ami Nabil. Ami is the term for father's brother and is also a word used as a sign of respect for an older man. As it happened later, Nadia married Ami Nabil's brother's son, Amal.

Very often, if the mother does not have any resources by herself, she goes to the women who are closest to her. They could be relatives or friends. Normally, there is a matchmaker that you go to that is not officially called this, but this person is accepted socially. My husband's uncle (father's brother) Ami Nabil, was such a person... In the case of my brother, Jamal, my mother went to Ami Nabil for help because he is well known for this kind of thing. He knows what to do. (Nadia) 
Frequently, the matchmaker does not make an appointment with the girl's family, but Nadia reported that Ami Nabil was usually good about making appointments "...because he does not want to be disappointed when people are not home." Several informants said many times the matchmaker will simply appear for the first visit to the girl's home because, again, these people know which girls are ready to consider marriage.

Nadia spoke about the subtle role Ami Nabil's wife, Huda, plays in assisting him in searching for a suitable bride for a young man.

It can also be that, for instance, Ami Nabil is looking for a bride, and his wife, Martami Huda (wife of father's brother) is his inner resource. She doesn't expose or reveal herself. She reports to him, and he is the one who likes to get the credit. (Nadia)

Once the young man has agreed to consider marriage, his mother begins looking herself. If she does not consult a matchmaker first, the mother alerts her female relatives and friends to begin helping in the search for a bride for her son. "Generally, it is an affair for women in the beginning." (Kamal)

Several informants also said that occasionally a man's mother will have a particularly strong influence in her family, and she would prefer, or even insist, that her son marry, if available, her sister's daughter, bint khelti, or brother's daughter, bint khale. The man's mother evaluates all likely candidates for a future wife for her son. When she has narrowed her choices, often with the help of friends, 
relatives or a matchmaker, she will go to her husband and say, "We think we have found the best girl. We ought to go and take a look." (Kamal)

For the most part, there is a preferred girl that is the first one that a man's family will consider for their son. This girl is bint ami, or father's brother's daughter. The familial connection is most important. Traditionally, because the Druze are endogamous within their kin group, and providing there are no problems between the families, they will seek out candidates from extended kinship positions, with bint ami being a first choice. When a young man is ready to marry, he may also have a female cousin offered to him out of courtesy, even though he has not formally expressed an interest in her. Such a case is described by Kamal regarding his sister, Nasrine.

My sister, Nasrine, was offered to my ibn ami (father's brother's son) out of courtesy. She is his bint ami. He was ready to marry, and we had to offer Nasrine's hand in marriage. We knew that he would not accept her, but if he had she would have had to marry him, even if she didn't want to. It is for the sake of our family honor. Of course, Arej would've never proposed for Nasrine if he knew our cousin wanted her. Arej is not a relative; he has no rights to her. (Kamal)

Please refer to Figure 2 for all of the possible female cousins a Druze man may consider to marry. "My family naturally wanted to marry family. That is basic, the family, the background." (Hdiye) Another informant states,

Traditionally, it was preferred that you marry a cousin. Especially, bint ami...or the closest to that, if there is one at that age, and if both 
families like each other. The father has influence in his family, he would want his children to marry to the closest relatives of his, which is his brother's daughter. It is still preferred today, but not pressured on. (Taymoor)

There are, traditionally, exceptions to this rule or preference for marrying a bint ami. Informants said that it is not common to marry a cousin who is widowed or divorced; however, a man who is handicapped or too old might not be able to find a young, virgin bride. He may be asked to marry his widowed or divorced bint ami because she is not a virgin. The man "... will keep her from being tempted to sin by sleeping with another man. God will also look with favor upon a man who keeps his cousin from sinning." (Sleman).

Several informants also referred to the instance where an older man might marry a younger, virgin bride. The role of the young wife would be to nurse or take care of her aging nusband, and when he died, she would inherit a substantial portion of his estate for her efforts. This type of marriage is also referred to in the literature of Druze marriages, as follows:

... what the Druse term "nurse-bride" marriages. In these unions an older man, often a widower, takes a younger bride to help cook, manage the household, and care for any infirmities he may have. A lower mahr is set because the wife can expect a reasonable inheritance upon the death of her aged spouse and may also anticipate marrying again. (Starr and Alamuddin $1984: 135$ )

As previously mentioned, brothers usually discuss any possible conflict of interest among themselves and their families before proposing marriage to a girl. Taymoor spoke 
to his older brother, Sleman, about a possible choice for a bride before he pursued his engagement. They talked about who was eligible to consider Lateefi for marriage. She is their bint ibn khale or the daughter of their mother's brother's son.

I remember talking to sleman about it... You are older than me, and out of respect, I should say it's your turn to get married before me... I want to ask you,....did you ever think of Lateefi as a wife? Sleman said he never had. I told him that I did not want it to be thought that I took her away from him. He had once mentioned that he thought Lateefi was nice and would make a good wife when she was older. So, when he said ok, go ahead, we did it. (Taymoor)

As can be seen from the above statement, there are several female cousins that a Druze man may consider marrying among his father's and mother's kinswomen. Although bint ami marriage still seems to be the preferred type, it does appear today to be a less stringent demand than formerly.

As can be seen from Figure 2, a diagram of Druze cousin marriage, a man has many women to choose from when seeking a bride. The bilateral aspect is illustrated by this diagram because the cousins are both the daughters of mother's siblings and father's siblings. If there are no cousins of marriageable age, from his father's or mother's descent line, girls from the man's home village will be considered. If local village girls are not acceptable or available, then the parents of the future groom will go to another village in the Shouf Mountains. It is possible that the prospective groom 
will have a girl he is interested in and approach his family about her, as Taymoor did in suggesting Lateefi to his mother. As discussed previously, after the man's mother has selected some possible family names from which to choose her son's bride, she goes to her husband to discuss her suggestions. The father of the future groom will determine which family is appropriate from their village or a neighboring one. "He would go through the proper, social channels. He would find out who the family is, their reputation." (Nasrine) The social acceptability of a girl and her family is of the utmost importance when considering her for a future daughter-in-law.

In the Shouf Mountains, all of the villages are wide open socially. Everyone knows everyone else. People are all vulnerable... However, there are things that remain secret, very few people know about. Supposedly, a girl is not a virgin? The father would want to know that. (Amal)

If the future bride is bint ami, or another match that has been planned between the families for many years, the role of the women in selecting possible girls is less pronounced. In talking about various cousin marriages, Nadia said,

If all of these girls are available, then the choice would be according to the son's taste. In the old days, when the children were born, people would reserve their children for each other...This is an old tradition now that is not really done anymore. (Nadia)

With these types of marriages, the negotiations for the mahr or brideprice is less complicated and more relaxed. 
Informants said that, traditionally, a young man would ask the advice of his family regarding his choice of a bride. Hdiye told her son Taymoor, "Look, I told you anybody, but of course, if it's going to be someone I like and know, I prefer it much better than anybody else." (Hdiye) Another informant said that he sought his father's opinion regarding a possible bride for him. This man stated,

I know my father always wanted one of us to marry one of our relatives. He wanted Kamal to marry his bint bint ab khale which is the daughter of Baba's (father's) mother's brother's daughter. (Amal)

After a prospective bride is selected, and agreed upon by the man and his father and mother, a series of visits begins to determine the possibility of a marriage/alliance between the two families.

2. Visiting the Young Woman and her Family to Consider Marriage

When the best possible choice for a bride has been agreed upon by the father and mother, informal visiting between the two families will begin. Some informants said that often other family members were also consulted, before deciding which girl would be selected. After family agreement, these informal visits can begin and stretch over a period of weeks or months. It is also possible, although not common, that a proposal may be made on the first visit. Responses from informants varied regarding the number of visits made to a girl before the man proposes. It appears 
that family circumstances determine how individual cases are handled.

very often the first visit to a girl and her family will be made only by the young man's mother and another female relative, possibly her sister or her husband's sister. Because each side always knows the purpose of these visits, even though it is not usually spoken of directly, the girl and her nuclear family are prepared for this first visit. Those family members present with the prospective bride include her parents and brothers and sisters living at home.

As previously stated, the number of visits appears to vary according to individual family situations. In addition, the man does not always go with his family on the first visits to the girl and her family; his appearance depends on how quickly negotiations progress between the two families. The specific visit in which a formal proposal of marriage is made seems to vary. In some instances, a proposal is made on the first visit, but this is usually due to extenuating circumstances. Two examples of proposals made on the first visit are discussed within the text of stage \#4.

The end of the first visit will set the tone for any future visits or indicate that there is no interest in a marriage between the two families. As the first brief visit is concluded, the head of the man's family (male or female) will give some indication that they are interested in the girl as a future wife. 
A phrase such as, "Thank you for making us welcome. We hope to see you again." may be used by the head of the man's family to show that there is an interest in continuing the visits. If the girl and her family are also interested in seeing the young man again, they will ask the family to come for a visit again very soon.

Generally, there is a third visit arranged between the two families if mutual interest remains after the first two. If there is any hesitation on either side, it may be only the women from the man's family who visit again. This occurred with one of the female informants, Nasrine, and will be discussed further on.

If a fourth visit is deemed necessary and appropriate, it is considered to be somewhat more formal than the previous three. If the women of the man's family have been the sole visitors up to this point, now is the time for the father and the young man to appear. If the son has not yet met the girl, he will be introduced to her at this visit by his mother. But, the young couple will not be allowed to spend time alone. As always, members of both families are present.

At this point, the informal and semi-formal visits are concluded. The man and his family will go home and confer over the necessary issues pertinent to the girl and her family. The girl will also discuss her feelings about the possible marriage with family from both her father's and mother's side. 
Referring back to the beginning of stage \#2, regarding the length of time it may take to select a girl to visit, Nadia offers this statement, "It is a long process to even choose a girl to consider for their son to marry. It can take three or six months." (Nadia)

There aren't too many rules about the amount of visiting that a man and his family does, but people usually get an idea of what the answer will be after the first or second visit. (Nabiha)

Nasrine said that her husband's mother, older sister and an aunt made three visits before her husband and his father came to visit. This was necessary because Nasrine's father was being rather difficult about her being approached for marriage at age 16 by a man who was ten years older than his daughter. Her husband is not a relative, but he is from the same village.

To further illustrate a woman's role in choosing brides, Hdiye said that in 1940 her husband's mother convinced her family that she knew of a girl she would like to have for her son. She further states,

My husband's mother went with her husband and

oldest son. It is the custom that the oldest son goes along on matters such as these. It is out of respect for his position in the family. (Hdiye)

Another informant, Nadia, discusses the role of elder siblings during this first visit to a girl and her family. She says that it is usually the father, mother and eldest married brother who make up the visiting party. Nadia insists that, if another brother is taken along, he should not be 
single. "..the girl might be confused about which one is interested in her. She might fall in love with the wrong brother." (Nadia) In Taymoor's case, his unmarried brother, sleman, went with him and their mother on the first visit to Lateefi's home. However, because Lateefi's father was Hdiye's nephew (brother's son), she had already spoken to her nephew and his wife regarding Taymoor. They knew at that first visit that sleman was not the interested brother. It was simply viewed as a courtesy visit.

Lateefi's father respects my mother very much. She told him what we were thinking; she asked them to give us their answer. If it is yes or no, it is ok. But, don't feel that you have to say yes or make us happy. But, she did the talking. (Taymoor)

Taymoor also stated that, traditionally, it would be the man's mother, older sister or close female relative that would make this first visit and sit with the girl. He says that they would get to know her and relay back a message to the man that the girl is, "...ok, she's not ok, she is fat, she is not fat. It is a getting-acquainted time." (Taymoor)

Hdiye said that she had heard from people in her village that someone from her husband's family was coming to ask for her hand in marriage. She had never seen walid, before, but because the two families were related (Walid's mother came from Hdiye's family, the Rimans), she knew many of his relatives because she participated in family gatherings as a child.

Nadia reports that she and her family already knew the 
purpose of Amal's first visit. Amal's uncle (father's brother), Ami Nabil, had acted as matchmaker for them and had made an appointment to visit. "It was prearranged that Amal was coming to visit my family. I knew why because Ami Nabil told my mother and father." (Nadia) She says that Ami Nabil explained that his nephew (brother's son) was looking for a bride, and he was interested in having Amal meet Nadia. That first visit, Nadia explained, is very brief, and the man does not bring his entire family. His parents and an older brother or sister may come too," ".. you show how courteous you are by being careful to not bring the whole household." (Nadia) Noor said that if a proposal is actually made during the first visit then "...good news can start spreading later."

If a girl and her family are not interested in continuing the visits because there is no wish for a marriage between the two families, informants stated that there are ways to be polite and yet discourage any further attention from the man and his family.

Among the Druze, you want to tell the truth, but people still want to avoid a head-on conflict or to be impolite or hurt anyone. (Kamal)

Informants also indicated that it is possible after the first visit that the man's family might want to do some more investigating regarding the girl and/or her family.

In Nasrine's case, it was still her husband's mother and a female relative that made the second visit to her home, about one week after the first visit. Nasrine's father showed 
interest during the first visit, but his tone was somewhat reluctant. Therefore, it was not the time for Arej and his father to visit yet. Kamal reports about the conversations during the second visit:

The man's mother will make an observation such as, "Wouldn't your daughter be a beautiful bride?" The girl's mother may answer, "your son is so handsome, he would make a fine husband." If, the answer is, "No, my daughter is too young to marry yet." then both parties know that there is no chance of a marriage. The matter is not pursued. (Kamal)

This happened to Amal on his second visit to a young girl and her family. Amal's father indicated that they wanted to propose, but the girl's father said he felt his daughter was too young yet and needed to finish her schooling before thinking of marriage.

Another tactic that the girl's family can use to indicate to the man that they have changed their minds after the first visit, is to not allow the girl to be present for the second visit.

...the man's family gets the message right away that the girl's family is not interested. There is no reason that is more important than to stay home for a visit from a possible future husband. (Noor)

If a third visit is necessary, as was the case with Nasrine, it may be an informal one for information gathering, or, a formal proposal may be made. Her third visit was still informal because of her father's reluctance. However, some encouragement was given by her father to Arej's mother, so 
that a fourth visit was arranged at which Arej and his father would also be present.

Usually, after two visits, you know why they are coming back for a third visit. You have already made up your mind, yes or no. Actually, if the visits have gone this far, your answer should be yes. If they are coming for a third visit, you know you must have an answer ready. (Nabiha)

If a fourth visit is arranged, as was the case with his sister, Nasrine, Kamal says that marriage is not actually mentioned, but "...everyone knows what they want, but they play like a cat and a mouse".

After all the necessary informal visiting has been conducted between the two families, the third stage in the Druze marriage process takes place. Each side will privately discuss the positive and negative aspects for a marriage, an alliance, between the two families.

3. Man and His Family Agree on Which Girl to Propose to

At this point, there have usually been at least two visits by the man and his family to the girl's home, or as in Nasrine's case, four visits. There are some exceptions to this pattern. Informants related their individual cases in which the agreement had already been reached between the man and his family before the first visit. These cases will be discussed in stage \#4 because the formal proposal was made on the first visit.

If the man does not like the girl that his parents have chosen or suggested for him, he can tell them so privately. 
In this case, no more visits would be made and the matter would be dropped, or, a second girl is chosen to visit for the first time. The visits would begin all over again.

Traditionally, the parents of the young man could insist that he marry a particular girl that they had selected for him. Although informants speak of hearing about these 'old days', they indicated that men today have some voice in deciding who they want to propose to.

Taymoor did consult with his mother (father deceased) and brother, Sleman, who lived at home with their mother. Sleman suggested Lateefi as a possible wife for Taymoor. She is a cousin of theirs, bint ibn khale. Taymoor felt that he behaved somewhat against tradition because he said that the ultimate choice of a bride was his decision, "...it is my life, I'm the one who will marry this girl." (Taymoor) He did not tell the rest of his family or relatives until he had proposed and been accepted by Lateefi and her family. It is possible that his sense of independence stemmed from having lived out of the Shouf for many years.

Hdiye spoke of her cousin, Mahmood, and of his mother's efforts to find him a bride. Mahmood asked to marry Hdiye, but her mother refused with the excuse that they did not want any problems to arise between the families if the marriage did not work. Hdiye's mother really did not like the fact that he was ten years older than her daughter, who was then 14. After their informal refusal, Mahmood's mother took him around to 
villages in the shouf to visit relatives and friends, seeking a bride. They would come home from these visits and discuss the various merits of the girls and their families. Eventually, they made a decision about a girl that Mahmood and his family could agree upon.

Taymoor said that, traditionally, it was the family name or the father's name, not the person, that mattered when the decision was being made to choose a spouse. "It's who's son you are: in the old days it took more weight in deciding who was to marry your daughter." (Taymoor)

One informant posed an interesting problem with regard to deciding to marry a relative: the possibility that the marriage may not work. Divorce is not common among the Druze, although it is allowed. It must be a rather serious matter to consider divorce, e.g., a woman unable to bear children, adultery, etc. Given the fact that divorce between relatives presents special problems, as Amal notes,

...if you are engaged or married to a girl who is not a relative, you can get out of it through legal process, whatever is agreed on in the delayed mahr. You just give it to her, and you don't ever have to visit her again... If it's a relative, you cannot stop visiting the whole family. You put hate where respect was. (Amal)

4. Formal Proposal of Marriage - Acceptance or Rejection

After a girl and her family are chosen by the young man and his family, a time is arranged for the formal proposal to take place. In some cases the proposal is made after two or three visits or perhaps more, depending on the 
feelings of each family. At this formal visit, the father of the young man speaks to the father of the girl. Informants reported that no ritualized words were used in making the proposal. The fathers will not speak of the engagement directly until later in the visit. At some point, the man's father will say nuktub khtuboui, meaning "We want to engage this girl to our son." (Kamal)

In the cases of Hdiye and Nadia, their future husbands proposed to them on the first visit. However, in both instances, these were special circumstances. As previously stated, Hdiye's husband's family wanted to get their son, Walid, engaged quickly and securely to the right girl so they would not worry about who he would marry. "Walid's family insisted on sort of keeping me for him. They knew it was too early for me to get married at 14." (Hdiye) Because the families of Hdiye and Walid were related, and Walid's father was a respected sheik, the proposal was more easily accepted on the first visit. Another reason that Hdiye's mother agreed to Walid's proposal was that there was the understanding that, with Hdiye being only 14, they would not marry yet. As was often the custom before world war II, Hdiye met walid for the first time during his family's first visit, although she had met other members of his family at weddings, etc.

Nadia's circumstances were somewhat different regarding her husband's proposal on their visit. Amal was 
then working in Saudi Arabia and so had limited time to search for a bride. Her family knew of this situation because of the friendship with Ami Nabil, Amal's father's brother, the matchmaker. Nadia said, "Actually, in my case, things were different. My husband's father proposed for me on the first visit." (Nadia) As she states, such a proposal was an exception to the rule, but one which did not present any significant problems for her family in accepting Amal's proposal.

I knew what they were coming for because of what Ami Nabil had told us, but I did not expect the question being asked so soon. I did not expect it on a first visit, because that is hardly ever done both socially and technically... I was actually ready to say yes, but I was just surprised. I had seen Amal's picture and liked it. I knew of his family and how good they were. I knew that it would be a good association for my family, too. (Nadia)

Nasrine had more of a problem with her proposal. As she related, her father was: "...being difficult, so more visits were necessary; five actually, before Arej asked for my hand." (Nasrine)

Taymoor also proposed on the first visit to Lateefi and her family. However, again, she was a relative on his mother's side. They knew he was working in Saudi Arabia and would not have time for the traditional, lengthy visitation process before the proposal is made. He related that because he was a relative, her parents allowed them a period of getting to know each other. 
...her parents didn't treat me the way that they treated their other daughters' husbands... I am a relative...I will protect her... I wouldn't

probably take advantage of her as somebody else. Honor is between us... Eamily honor... I must

think of my honor to her and her family. ( Taymoor)

Hani related that his was an easier process leading to the formal proposal because he and Nabiha were first cousins (his mother and her father are sister and brother) and had known each other all of their lives. He took his mother and uncle (his father was deceased) with him to formally ask for Nabiha's hand in marriage. In addition, Hani's brother, Osama, married Nabiha's sister, Dalal.

Female informants verified that they had the option to refuse their marriage proposals. However, this is almost always with the consent of their families, and traditionally, important relatives are consulted about any proposal. Hdiye refused two proposals, with the assent of her family, before accepting Walid's proposal. She said that she could have refused walid too, if she wanted to, "...But, had I stood up by myself and said no, without the support of my family, I would not have had a chance. I would have to agree with them." (Hdiye) During the years before World War II, Hdiye explained that the girls were young when they got engaged, often 14 or 15, and so needed the advice of their families to help them decide upon accepting or rejecting a proposal. It still appears to be the case today because Nasrine, Nabiha, Noor and Nadia all 
discussed their families' roles in helping them to decide about their proposals.

Hdiye made an interesting statement regarding the changing of tradition in accepting a proposal.

Today, the girls have a choice. If the girl does not want to marry the man that her family wants her to marry, she will threaten to commit suicide...My daughter, Nasrine, wanted to marry Arej, and, at first, my husband refused. She said she would do so anyway, but we knew he was a good man... Girls are wiser and more educated than in my day. Today, they can stand firm and get away with it. The market is good, there is no shortage of men or women to marry. (Hdiye)

After the proposal is formally made, informants said that the man and his family may get an answer at that visit, or may have to wait for other family members to be consulted. The girl and her family may give an excuse about waiting so that the outcome is ambiguous. One informant quoted a folk expression,

We say oats...for no. The kind you feed the animals. Or, we say wheat...for yes. Wheat is soft. Oats have tiny, sharp edges. So, oats is tougher to chew, and they hurt and stick. So, it (answer to the proposal) is either wheat or oats! You can tell! (Kamal)

If the answer to a formal proposal is yes, then the next step in the Druze marriage process is negotiations of the mahr (brideprice).

5. Mahr is Negotiated and Marriage Contract is Drafted

Stage \#5, in the Druze marriage process, begins after the proposal is accepted. According to all informants, this step is really the most significant in the marriage process. 
The Druze regard the mahr as "...a symbol, a ritualistic demonstration of the groom's esteem for the bride." (Starr and Alamuddin 1984:133) The future of many marriages can become embroiled in rather difficult negotiations regarding the advance and delayed mahr. The mahr, or brideprice, consists of an advance payment and a delayed one. The terms of the mahr must be agreed to by both families before the exchange of engagement rings can take place.

The advance mahr is usually, according to all the informants, a selection of gold jewelry and other gifts that the groom buys for the bride. Nadia states that, "...such things as gold bracelets of certain carets, necklaces, earrings, additional diamond rings, maybe a watch, and a wardrobe." (Nadia) She also indicated that the amount of money the groom spends is subject to the income of his Eamily and himself.

Other items mentioned by these research informants as being traditionally included in the advance mahr are a sewing machine and "...a cupboard or moveable closet for the bedroom". (Hdiye) A complete bedroom furniture set was also mentioned as a possibility. Often times carpets and lighting fixtures may be added to the list. The agreement for providing the bride's new clothing is included in the advance mahr. However it is not prepared until later. This will be discussed in stage \#8. 
Taymoor related the story of the formal shopping trip he took with his future bride, Lateefi, his mother and sister-in-law. He said that the cost of the jewelry that he bought for Lateefi was worth approximately $\$ 1,000 \quad(35,000 \mathrm{LL}$ in 1986). When asked how he decided what amount of gold jewelry to buy he replied,

Well, I decided it with Lateefi. When we went out, we just picked out what we had agreed on. Every time I decide something with her, I'm sure she relays it back to her parents. Her parents give her the ok. (Taymoor)

In Nasrine's case, as she stated, her father was being somewhat difficult regarding her mahr, so her older brother, Kamal, stepped in to help. Nasrine said that she felt desperate because she was afraid that Arej and his family would lose interest in her. She was quite happy when Kamal came from Europe, where he was working, to try to work with their father. He was successful in negotiating a mahr that was agreeable to both families.

When Amal was questioned about the mahr he paid for Nadia, he reported that he bought various pieces of gold jewelry, a diamond watch and expensive cloth for Nadia's mother to make her new clothes. He said he spent, in 1982, nearly $35,000 \mathrm{LL}(\$ 10,000)$ on his advance mahr for Nadia. The amount of the delayed mahr is also discussed and agreed upon at this time. It is written as a formal document and will be legally recorded at the Druze court. 
The delayed mahr is paid by the groom, and/or his family, only in the event of a divorce.

Informants reported that in 1984 the Sheik al-Akkel, religious head of the Druze community, instructed the courts to set a limit on how much money could be asked for a delayed mahr. It has become a serious problem with regard to status of the bride and her family. "...over the years people began to get a little bit arrogant." (Hdiye) She related the story of her husband's niece (brother's daughter), who was married about 18 years ago in the shouf. At that time no amount had to be specified for the delayed mahr. Each family wrote a figure according to their financial means. When this niece was married, her family asked for a large amount to be written for her delayed mahr: 25,000 LL. (note: It was difficult to ascertain the U.S. dollar equivalent for this figure, but informants suggested a possible figure of $\$ 10,000$.$) This young woman's father$ was an important businessman while her mother was a headmistress of a private girl's school in Beirut, and she was marrying a promising attorney. When the amount of her delayed mahr became known through gossip, it was said by others, "If Abeer Khattār has 25,000 LL for her mahr, then I want $25,000 \mathrm{LL}$, too." (Hdiye)

As a result of this unusual amount being written for the delayed mahr, many people began to ask for exorbitant 
amounts of money, amounts that became impossible for the groom's family to risk in the event of a divorce.

Sleman discussed his problems with the delayed mahr when he was negotiating with Noor's family to marry her. His family finally wrote the amount of 10,000 LL because that was all they could afford. Taymoor also had problems with Lateefi's family regarding the delayed mahr. His older brother, Mahmood, finally went to her family and explained that the amount they could afford to write was only the maximum allowed by the law, 25,000 LL and no more. Taymoor describes resolving his conflict with his cousin (mother's brother's son) and future father-in-law, when he was told, "You are buying, we are not selling our daughter. Rather, we are buying a son-in-law." (Taymoor)

Nadia stated that it was her father and Amal's father who agreed upon the amount of the delayed mahr. In 1981, her mahr of $25,000 \mathrm{LL}$ was worth approximately $\$ 5,000$. She also said that Ami Nabil, matchmaker and uncle (father's brother) to Amal, was involved in the discussions of the mahr.

In addition, informants said that some furniture could be written into the delayed mahr, and today the sewing machine could also be delayed. It appears, after interviewing the female informants, that the sewing machine is not as important to them today as it was in the days prior to about 1970 . 
Because of the restrictions set by the court, if both families wish to do so, informants disclosed that a new practice has begun where a separate, legal document is written for additional delayed mahr. This practice has become common as a hedge against the runaway inflation of war-torn Lebanon during the last five years or so. In 1988, the value of the required 25,000 LL for delayed mahr had dropped to approximately $\$ 80.00$

At the time that the advance and delayed mahr is being discussed, the marriage contract is also agreed upon and drafted for the Druze court. It will be formally registered there on a date that is agreed upon by both families. It is rare that the bride and groom would be allowed to spend any time alone before the formal registration of the marriage contract, katabet elekteb.

The only exception to this restriction, occurred in the case of Taymoor. He was allowed to spend some time with Lateefi in her home where they were not directly chaperoned. A family member would be in the house but often in another room. If they ever went out, it was always in the company of family members from each side. As stated previously, Taymoor cited kinship and a sense of family honor on his part as being reasons why he was allowed such unusual privileges with Lateefi. Her older sisters were not allowed this same freedom when they became engaged to young men who were not related to them. 
6. Payment of the Advance Mahr

This is actually a relatively simple step in the marriage process because no negotiations are necessary. The engagement has been agreed to and the amounts for the advance and delayed mahr negotiated, as well as the marriage contract being drafted.

Informants seem to agree on a normal time limit of six months to one year for an engagement. The time does not officially begin until the advance mahr is paid; however, families can make their own exceptions due to individual circumstances. Hani said that he was 26 when he became engaged to Nabiha, however,

... we had to wait until 1970, for five years, before I could marry Nabiha. I had to get money to pay for the mahr and to show that I could afford to set up a house. (Hani)

Taymoor paid his advance mahr on the day he went with his family and Lateefi to shop for her jewelry. Nadia related the same story concerning her shopping trip and Amal's discharge of his payment of the advance mahr. In the case of Nadia and Amal, he accelerated his payment because they were moving rapidly through the stages, in order to speed his return to Saudi Arabia.

Traditionally, as soon as the advance mahr is paid, the formal exchange of the engagement rings can take place. After this stage, the man has a little more flexibility in visiting with his fiance. 
7. Hatou El-Khutbi - Formal Exchange of Engagement Rings

The phrase hatou el-khutbi means "they have exchanged the rings". This event traditionally takes place at the bride's home. Once accomplished, people say maktoubeen, "they are engaged".

Hdiye spoke of the seriousness and restrictions that were placed upon a couple about to be engaged. She said that Walid, accompanied by his parents, brought the engagement ring to her mother's home. Although it was unthinkable at that time, he placed the ring on Hdiye's finger himself. "You see, the bride and groom were not supposed to touch or hold or anything. Walid said, "No, I am going to put this ring on her hand or else." So they let him." (Hdiye) Afterwards, her mother suggested that she should not wear her engagement ring in public because people would gossip that, at 14 , she was too young to be engaged. She did follow her mother's wishes until walid came to visit her sometime later and became upset because she was not wearing her ring. Hdiye said that he told her, "I don't accept that, it looks as if you aren't married." (Walid as told by Hdiye)

Informants agreed that today there is usually a simple, intimate gathering to celebrate the formal engagement. The larger celebration, the urs, is saved for the wedding day. One factor that can affect the size of the engagement party and its location, is a death in the family. 
Taymoor said that Lateefi's grandfather died just a few months before they were engaged. As a result, out of respect for her family and the memory of her grandfather, Taymoor and Lateefi exchanged their engagement rings at her home and then joined his immediate family at his mother's home for a small luncheon.

We just could not feel comfortable holding a big party with drinking and dancing even though he was dead four or five months before... We couldn't have the party at Lateefi's home. They wouldn't want people to think bad of them. (Taymoor)

Taymoor did say that traditionally the engagement party is a small affair, but today some younger Druze are having larger parties with music and dancing, often western style dancing. Their relatives and friends are all included. He said that if it had not been for Lateefi's grandfather dying so recently, he and Lateefi would have arranged a larger party for their engagement. Taymoor called this change "a question of modernization".

As stated at the end of stage \#6, once the payment of the advance mahr has been made and the formal exchange of engagement rings has taken place, it is possible for the groom to visit the bride in a more relaxed manner. He may visit his fiance at her home, and they may sit alone together in the living room or on a balcony.

Obviously, there is a limit on how far they can go. They can only sit somewhere where they can be seen. They don't actually have to have a chaperone, a person sitting in with them. The 
man, of course, can't go to her bedroom. (Sleman)

Hdiye relates a story that illustrates the rights of men and women as recently as 50 years ago. When she was engaged at 14, she had an older brother who was in the Army and not home much, and a younger brother aged 12. Walid was also in the Army, stationed in Tyre, and often difficult to reach. Hdiye said that when walid came to visit her, "...My younger brother was very strict because our father was dead...so he would not allow me to see walid when he came to visit me." When asked if her mother could control the brother's actions at such an age, Hdiye asked, "But what could we do about Farid? That was 50 years ago now. I could not do much even though he was acting a little foolish." After reading the historical description of men's traditional influence over women in Seabrook (1927), it is easier to see how Hdiye's twelve-year old brother was able to exercise such control over Hdiye and their mother only 15 years later.

Hdiye also related the story of how walid would come for a visit to see her, and if Farid was home, he would not let Walid see Hdiye, even though they were formally engaged. In her absence, Hdiye's mother and Farid would entertain Walid in the living room.

I would try to walk past the closed door. There was a wooden door with a little hole in it, I would try to look through the hole. Farid found out about it and sealed off the hole. I don't know why he acted that way. (Hdiye) 
She goes on to say that this same young, strict Druze boy grew up and married a non-Druze woman, a Christian. It was walid who helped him through all of "...the family misery that he faced when my family would not visit him because of the woman he married." (Hdiye)

As previously stated, there is now some flexibility for the man to visit the bride at her home. There are occasions when the couple are allowed to sit with each other while a family member is in another room of the house. Each of the informants attested to this recent development. Taymoor and Hani also said that the reason they were allowed more time alone, within the prescribed boundaries, with Lateefi and Nabiha, is because they were marrying cousins. The familial ties and sense of honor are deemed stronger, in the treatment and protection of young women, when they marry within the kin group.

Nadia was asked if after the couple are hatou elkhutbi, they could go for a walk alone. She said that this was not an accepted activity, because there would be a period of time when the couple might be entirely alone, away from people. She insisted that it would be discouraged, not because they were not trusted together, but for the sake of the girl's public reputation.

... if something were to go wrong three months after the engagement,.... and the engagement is broken, then nobody will want to marry the girl. People would know that she had been in the car or on a walk with somebody else,... something 
could go wrong, you never know. Anything counts among the Druze. (Nadia)

Taymoor said that he and Lateefi were allowed, after they were engaged, to ride in a car alone, but only when traveling to visit his parents or other family members and returning directly to her home. This could only happen once or twice a month. Again, he reported he was allowed more freedom in visiting with Lateefi because he was her cousin. Sleman and Amal's accounts are in agreement with the description provided by Nadia above. Nasrine said that Arej was not a cousin and their movements were closely chaperoned, after their engagement, until they married.

There are occasional behavioral variations between this stage \#7 and numbers 8 and 9 . On occasion, if there is a reason for speed, a couple may do their katabet elekteb, "writing the contract", on the same day as their engagement. This will be discussed in stage \#9.

8. Khas Al-Jehaz - Preparation of the Bride's New Clothes This eighth stage in the Druze marriage process means "cutting of the cloth". This activity involves the cutting of the cloth for the bride's new clothes which she takes to her new home. The bride and her mother also prepare her lingerie, household linens (i.e., sheets, pillows, and blankets, etc.), handcrafted embroideries, crochet work, etc. 
Traditionally, the bride and her kinswomen cut and sewed her white wedding gown and the new clothes for her marriage. The groom paid for the cloth for the bride's wedding dress, new clothes and lingerie.

Today, informants said that many brides buy their wedding gowns, new clothes, lingerie and bed linens readymade. This is, perhaps, the reason that young women do not feel a sewing machine is so important to their advance mahr payment. However, tradition dictates that the mahr is still written this way, and each of the young male and female informants described a sewing machine as still being part of their advance mahr.

Hdiye remembered her trip to Beirut in 1941 to have her wedding dress made by a professional seamstress. Noor, Nasrine, Nabiha and Nadia all said they bought their wedding gowns in shops in the shouf Mountains or ordered them from Beirut. Each of these women also described other friends and relatives who purchased their ready-made gowns from shops.

Nadia was an exception to the current practice of buying her wedding clothes. She said her mother is a wel1known seamstress in her town and sewed all of her new clothes. Amal paid for all of the cloth. If her mother had not been able to make her clothes, Nadia said she would have bought them.

My mother sewed dresses, blouses, skirts and tops for me. She included all of the necessary 
clothes that an elegant young girl required to take with her into her new life. (Nadia)

All of the female informants discussed their preparation of handcrafted items such as embroidered tablecloths and scarves, crocheted work, tatting, etc. The young women made these things for their new home, as well as receiving such items as gifts from their kinswomen. More of these handmade pieces are also presented to the bride by her mother on her wedding day. These will be discussed in greater detail in stage \#11, sandit al-arous, or the "display of the bride".

9. Katabet Elekteb - Signing the Marriage Contract

"Writing the book" is the translation of katabet elekteb. It occurs on a specific date that has been arranged between the bride and groom and their families. They go to the Druze court to formalize and sign the marriage contract according to the terms previously drafted by the two families when the mahr was agreed upon. Witnesses, both families and the bride and groom, are all present.

It is also possible that katabet elekteb may be done the same day, or soon after, the formal exchange of engagement rings, as described in \#7. There are examples from informants to illustrate this combining of stages, and these will be discussed also. 
A second step, carried out on the same day as the katabet elekteb, is the recording the delayed mahr. It is entered into the legal register at the court and the court clerk writes a document that states the amount agreed upon for the delayed mahr. He puts this in an envelope and officially seals it.

There are some steps that must be taken before the couple can actually go to the court for katabet elekteb. An official document is obtained by both parties that has the following information on it: name, age, mother's name and age, father's name and age. If one of the parents is deceased, the death date is listed. This document affirms (by oath) that both parties are single, and it is certified publicly. A doctor's examination and blood test are required and must be certified by the doctor. Blood types are checked for diseases so that the couple will have no problems in producing healthy children. However, Taymoor, said that the doctor's certification can be obtained by simply paying money for the document, but specified that this practice seems to have arisen since the beginning of the civil war in 1974. "It has to be a government doctor. They will go to the court and say what time and which day we will go there." (Taymoor)

Nadia explained that it is possible for the katabet elekteb to be done at the bride's home, if the couple would prefer this occasion to be more private. All of the steps, 
questions and registration, remain the same as if they were all performed in the court.

Taymoor and sleman said that it was not legally necessary for their parents to be with them at the court. The men only need two witnesses, but the bride needs her parents as well as two witnesses. The bride and groom present all of the necessary documents and their Lebanese ID cards to the Druze judge and a clerk records all of the information.

The young couple and their families stand before the judge of the court. The groom and his family tell the judge that they have given all of the advance mahr, and they list the contents for him. "...The judge asks the bride, 'Have you seen these items? Have you received these things?' She will say yes, and he tells her to sign the contract. They write down the delayed mahr." (Haiye) The complete mahr is again listed for the judge, and the groom and his family tell him that in case of a divorce, the bride will get all of these items and the money from the delayed mahr. The Sheik/Judge says a prayer "...asking God to make this marriage contract a happy one, and that was it." (Sleman)

Hdiye said that the actual procedure of katabet elekteb is still the same today as it was when she married in 1941. She has repeated the same steps when her sons and daughter have married: the most recent one being 1987. The only significant change has been in the amount of delayed 
mahr recorded. "You go by what the market decides."

(Hdiye) She described the amount of delayed mahr when she was married as $100 \mathrm{LL}$ that was paid in ottoman coins called Osmali. She and her son, Kamal, determined that this 100 LL would be worth approximately 30 cents today. A discussion of the amounts of delayed mahr can be found in stage \#5.

The informants were questioned about what happens to the officially sealed envelope containing the delayed mahr. Most agreed it was given to the bride's parents for safekeeping in case of a divorce. Contrary to tradition, Amal said that Nadia's parents gave his envelope back to him two or three years ago. Taymoor reported that his delayed mahr was given to Lateefi's parents by the court. Hdiye said her envelope was given to her male guardian and relative. She was asked where this envelope was after all these years, now that her husband had died. She said she was not sure but assumed it was still in her family's home, in the possession of the cousin who now lives there.

I have never asked for it back. I have no right to ask for it anyway because my husband is dead. He can't divorce me now... It does not belong to me. It belongs to my family. It was for my protection, in case of divorce, and for my family's too. (Hdiye)

Most informants agreed that by performing katabet elekteb, the bride and groom were allowed more freedom of movement with each other. The couple is considered legally married at this point, even though they may not be living together yet. 
Nadia explained that she and Amal's case was unusual because he was working in Saudi Arabia and not able to come to Lebanon very often. Amal's father suggested to Amal that they register their contract, katabet elekteb, as quickly as possible. Because Amal had a limited amount of time in Lebanon on each of his visits, Nadia and Amal could then spend much of that brief time together. "This way we would not be restricted socially by the fact that we were not yet married." (Amal) According to Druze law, once the marriage contract has been written, whether the couple lives together or not they are then considered legally married.

Another reason to write katabet elekteb soon after the engagement concerns Lebanese Army regulations. As soon as this stage is completed in the Druze marriage process, a man can start to collect support pay for his wife, even if they are not living together. If the couple needs financial help to set up a household, this salary is often saved for their first home. This army regulation was mentioned by Nadia, Taymoor, Kamal and Sleman.

The Lebanese civil war is another factor often referred to by the Druze informants with regard to army service and its effects on katabet elekteb. There are more men in the army now, so the demand for family benefits has increased dramatically. Because of the war, there are also many men who must go abroad to find work. When these men 
come home, they wish to facilitate the process of finding a wife. "In my case, it was all done in 10 days." (Nadia)

The next stage discussed in Druze marriage is elekteb maktoob, or "the book has been written".

10. Elekteb Maktoob - Legally Married

Elekteb maktoob means "the book has been written".

This time period can last a few days or even several months. It depends on the circumstances of the couple and their families. When Nadia and Amal completed katabet elekteb, she remained at her parents' home for another year before they had the wedding celebration or urs.

Hdiye remained with her family, as did Nadia, (for about one year) after katabet elekteb. Hdiye and walid did not have the money right away to provide a house, but completing katabet elekteb ensured reserving Hdiye for Walid. Taymoor and Lateefi signed their marriage contract in 1987, and she remains with her family. Taymoor works in Saudi Arabia and visits her when he can. He is having trouble getting a visa for her to join him, so they have not had the final urs. They will do this when they can begin living together.

There is one aspect of this stage in the marriage process which is unique to the Druze. There are social and religious guidelines that operate here. This stage, elekteb maktoob, recognizes the couple as legally married. However, it is not acceptable for them to sleep together until they 
can actually establish a residence together. Their first

residence can be with his parents or, in their own independent quarters.

"It allows the man, technically, marriage rights with his wife. But, the mothers on both sides discourage it...A husband can demand his rights, but it is generally not done." (Kamal)

Nadia said that no one would ever know if she slept with Amal, but it is not spoken about publicly. She insists that it is not socially respectable to sleep together.

In Druze life, the social life is very important. The social image can create a lot of problems. The social part of our lives also affects the mental and emotional part of our lives. If my husband and I go to bed together before our wedding celebration and I get pregnant, then people would know that we had slept together. So, we would not want to take such a chance. It would be very embarrassing. (Nadia)

Nadia also states that it would have been acceptable for her to stay with Amal's family during elekteb maktoob, but it was more convenient for her to stay with her own family.

Taymoor has a somewhat different opinion of this time period. It is difficult to surmise whether his feelings stem from the fact that he is a male or that he now has less traditional attitudes because he is living abroad. He refers to this period after writing the contract as "official prostitution". He goes on to say,

"You cannot sleep together, but if anything happens, she already has her rights. See, you pay for it, you get it. If I left her now, I 
would have to pay the delayed mahr too." (Taymoor)

This young Druze informant says he believes that the attitudes are changing in the shouf, and that "probably" there are young couples that do have "some sort of physical relationship" before living together. (Taymoor)

Once the couple are ready to live together, be it immediately or for months after katabet elekteb, the next stage involves preparation for the wedding celebration, at the home of the groom's parents.

\section{Sandit Al-Arous - Displaying of the Bride}

This event takes place at the home of the bride. She dresses in her white wedding gown and veil, puts all of the jewelry from her advance mahr on, and sits on a speciallyprepared bride's chair, kerset al-arous, for all of her guests to see and admire. She sits on this chair for approximately two to three hours while her immediate family, relatives and friends come to congratulate her and admire her gown and jewelry. She will sit and wait for the arrival of the groom accompanied by his friends, to take her back to his home for the urs. There is also a special chair reserved for the groom when he arrives. Guests are sexually segregated, with the women gathering with the bride on the kerset al-arous, and the men gathering in a separate room. When the groom arrives, his male guests join the men already 
present and his female guests will join the women with the bride.

As stated above, the bride dresses in a white gown (foustan) and a white veil (tarha). The bride's mother also gives her a small piece of paper, folded in the shape of a triangle, with prayers from the Kutub al-Hekmeh (Books of wisdom) written on it. She may also give her daughter some barake which are small, brightly-colored strips of cloth that come from Nabi Ayoub. These barake are from the most sacred shrine in the Shouf Mountains and are believed to bring good luck, happiness, and good health.

This gathering at the bride's home is not a large celebration because there it involves some sadness for the bride and her family. As described by several informants, a daughter is leaving the house. "They are happy for the bride, but not joyful to have a child leaving. It is a sensitive time...You are watching a child leave home forever." (Nadia) This same description can be found in the historical accounts of Druze marriages given at the beginning of this chapter.

There is no food prepared at the bride's home because it is not considered a celebration; however, sweets, coffee and light refreshments are prepared to offer to the bride's guests and to the groom and his guests when they arrive. "The bride's family is not the ones who are celebrating, but they are wishing the bride and groom well." (Nasrine) 
During this time at the bride's home, her mother also presents her with jehaz al-arous, or, "a hope chest", that she has prepared for her daughter over the years. It is put on display for all to see, and contains sheets, pillowcases, doilies, dresser scarves, serving tray scarves, tablecloths and napkins. All of these items are handmade, embroidered and crocheted by the bride's mother and often older kinswomen of the bride.

Guests to the bride's home also bring wedding gifts for the new couple. These "gifts for the bride", afish alarous, consist of household items such as dishes, plates, glassware, pots and pans, silverware, etc. Sometimes, depending on the degree of closeness and financial position of the bride's family, a refrigerator, television or other large appliance may be given. Kamal bought his sister, Nasrine, a washing machine when she married. Noor stated that because there is not a great deal of variety in the shops in the shouf, it is possible to get many duplicate wedding gifts.

Nadia also explained that due to the political situation existing in Lebanon at the time of her urs in 1982 (the Israelis had invaded the shouf just about two months before) travel was restricted. She states that they did not get many wedding gifts because there was not much to buy in the shops in the shouf. These gifts are taken with the bride when the groom comes to call for her. Again, this 
matches the historical description presented at the beginning of this chapter.

The kerset al-arous that the bride sits on to receive her guests is elevated, covered with carpets and a fine cloth, and decorated with flowers, fresh greens and sometimes with ribbons. "They want it to be as perfect as possible, when the groom comes to pick up the bride." (Nadia)

\section{Naklet A1-Arous - Transfer of the Bride}

This is the formal transfer of the bride from the protection of her father and brothers to that of her new husband. It has been described by informants as being difficult for the bride who leaves her childhood home, but happy for the groom who receives his new wife. The groom and his family and friends transport the bride back to the groom's home for the wedding celebration.

Hdiye spoke of walid coming for her in a car with friends to take her to Beirut where he was stationed in the army .

We gathered all of my belongings, clothes and everything and put it all into one car. We put in bedspreads, sheets, pillows and everything to speird the night in Beirut. We traveled in several cars to Beirut... There used to be two brothers who were famous at helping at these kind of celebrations. One brother had a car that Walid borrowed, or that he took me in it to Beirut. The other brother was a poet. So, the poet recited zajel (spontaneous recitation of original poetry) to us on the way to Beirut. (Hdiye) 
Hani spoke of going to get his bride, Nabiha, in their home village, and then going by a procession of cars to Beirut, where he was living at the time, to hold the wedding celebration there. He said that Nabiha wore her white wedding dress as a "sign of virginity" in the car enroute to Beirut.

Nasrine and Noor indicated that often the size and importance of the naklet al-arous is judged by how many cars can be seen in the procession which takes the bride to the groom's home. Nadia said that her wedding was a quiet one because of the political situation at the time in 1982, and the fact that Amal's father had died just six months before.

Nadia related the scene of Amal's arrival at her home during sandit al-arous. She was sitting on the kerset alarous. They had wedding pictures taken on and near it, and each greeted the other's guests. Light refreshments were served to Amal and his guests.

My father and my oldest brother escorted me out to the threshold of the door, and I was transferred from my father's house to my husband's. The naklet al-arous is a symbol of transferring me, the bride, from one way of life to another. It is when I take my first step outside of my home to the other side of the doorstep. I am presented by my father and oldest brother to my new husband and new life. The groom, Amal, steps forward to receive me escorted by his father and oldest brother. (Nadia)

Nadia said that because Amal's father had died, his father's brother, Ami Nabil stood with him, and his oldest brother in Lebanon at the time, Mahmood, also came with him. 
Informants also related stories of brides still being transferred by horse and buggy. They confirmed that it was the old, traditional way of naklet al-arous, but that people did this more for show today. (Hdiye, Kamal and Sleman) Hdiye said that cars were used after the roads became better in the late $1930^{\prime} \mathrm{s}$. Kamal related one story from his childhood in the 1950's where a bride was being transferred in a horse and buggy, but "...the horse would not move, it was embarrassing." (Kamal)

During this author's trip to Lebanon in 1988, there was an opportunity to witness a naklet al-arous from the home village of the groom to the bride's village, about 30 minutes away by car. There was a long procession of cars, approximately 20, with horns honking, following the groom's car which was decorated with flowers and ribbons. The groom was driven by a friend or relative in the lead car.

However, there was a modern twist to this age-old procession. There was a car in front of the groom's car with a man holding a video camera, bracing himself on its hood. He was aiming the camera back toward the groom's car and the procession, filming the trip to the bride's home. When the procession returned about three hours later, with the bride in the groom's car, all of the cars were honking and occupants waved at people along the road. The video cameraman was, again, on top of the car in front of the 
bride and groom, filming the procession back to the groom's home and the urs.

13. Urs - Wedding Celebration at the Home of Groom's Parents

This celebration, traditionally, takes place at the home of the groom's parents. It can be held the same day as signing the marriage contract, katabet elekteb, or months later. This was the case with several informants, as was explained earlier. The urs does not begin until the bride arrives with the groom. Again, the historical description given in the beginning of this chapter illustrates that little has really changed in this part of a Druze wedding. There is food, prepared by the mother and kinswomen of the groom, music and dancing. The size and level of activities can vary according to individual circumstances of each family. Nadia said that their urs was actually held at her parents' home because Amal's father had died just six months before, and it was considered more appropriate for the family in mourning not to have a large celebration at the home of the groom's family. It was also a difficult time, politically for the shouf because of the Israeli presence, so traveling was restricted between villages. Nadia's village is about one hour by car from Amal's. Hdiye and Nabiha both described their wedding celebrations in the homes of the grooms' parents, in Beirut. The celebrations although held 30 years apart, were much the 
same in substance. Hdiye said that before World War II, it was traditional for the urs to last two or three days. After serious political problems developed in Lebanon in 1958, people became more conservative when celebrating weddings. Nabiha was married to Hani in 1970 and said that their urs lasted for two days, but no one really began to dance at weddings again until the 1980's. Taymoor spoke of recent urs, where people danced, often "disco", but that this activity depends on whether the presence or absence of sheiks or sheikas. If such persons are present, there will be no alcohol and no dancing. Sleman and Noor had a quiet celebration because his mother is a sheika and it was not considered respectful to have alcohol and dancing in her home.

All of the informants spoke of the urs as being the most important part of the wedding process because it signifies that the bride and groom could now live together under the same roof.

\section{Beit Al-Arees - Home of the Groom}

The newlyweds' living quarters have been, traditionally, the home of the groom's parents. Again, this can be seen in the historical description given in this chapter.

However, this seems to be changing now. Taymoor and Sleman spoke of a trend for the newly-married couple to live in their own separate home. "The young girls want their own 
home now; they do not want to live with their mother-inlaws." (Taymoor) sleman wanted to build his own home before he even thought about getting engaged, even though his widowed mother would live with him and Noor. Taymoor also spoke of pressures from Lateefi and her parents to build their home in the shouf, even though he is working in Saudi Arabia for the foreseeable future. The house would only be used on vacations. He said he got into an argument with her parents because they also wanted him to furnish the house too, even though "...it would just sit there and gather dust." (Taymoor) Finally, her parents gave up on the idea of furnishing the house when Taymoor said he would back out of the marriage if all they cared about was a house.

All of the informants indicated that the trend toward young women wanting their own homes is now widespread in the Shouf: a breaking of the traditional pattern. However, the familial ties of the young couple are quite strong, and it is common to establish the new, separate home in an apartment on top of the groom's home, or at least rather close by.

This completes the stages in the Druze marriage process, and it can be seen that these 14 stages illustrate a long and convoluted process. The evidence shows many variations on the traditional pattern, with consideration given to individual circumstances. Chapter $V$, which 
follows, will analyze the Druze marriage process and its adaptations, and show where the traditional patterns have been altered and where their basic structure, their orbits of organization, have changed very little. 


\section{CHAPTER V}

\section{CONCLUSIONS}

1. The ethnographic data assembled here clearly indicates that Druze marriage practices still follow the traditional pattern. The fourteen stages in the lengthy and elaborate marriage process have not been changed except for minor variations such as the bride buying her bridal gown from a shop, transfer of the bride to her new home by car, not horse, and permitting both men and women to attend the wedding celebration party. Marriage partners are still chosen from the local village, and preferably, they are patrilineal parallel cousins or bint ami (father's brother's daughter) marriage.

2. However, though the basic pattern is intact, modern social, economic and political conditions have had some impact on aspects of the marriage process. The key factors producing adaptive changes are: the stresses of civil war in Lebanon, male employment outside the Shouf Mountains, severe inflation, female education and employment outside of the home. These changes are reflected as variations on the traditional cultural pattern.

Today, both potential marriage partners may have somewhat more influence on deciding who they marry. Men are 
more independent, economically, and women, more educated than formerly and so the complex financial bargaining by the kin groups now may include the opinions and desires of the engaged couple in such matters as choosing the specific items in the bride price such as furniture and jewelry. Due to financial stresses caused by inflation, the traditional, formally fixed sums of the delayed brideprice are no longer acceptable, while the groom, himself, is increasingly held financially responsible for it rather than his kin group. Also, the family of the bride may now insist on a separate legal contract to protect their financial interests in case of divorce because the traditional marriage contract, validated by the Druze court, is no longer considered an adequate protection.

Finally, the classical pattern of patrilocal residence after marriage is beginning to give way as an independent apartment or house becomes the preferred choice of those who are less tradition-bound and affluent enough to afford it. 3. Druze marriage obviously functions to keep the traditional pattern of Druze social organization intact. By selecting mates within the patrilineally organized kin groups and the local village, kinship and community are closely bound together. Ethnic identity is not solely dependent on religious ideology, but on a tight social order whose glue is largely supplied by marriage alliances. Only a formal Druze marriage involving two Druze confers 
legitimacy on any offspring as full members of the Druze community.

Druze marriage customs, in the Shouf Mountains of Lebanon, have shown a remarkable resiliency over the last 150 years. This same conclusion was drawn by Alamuddin and Starr (1980) after researching marriage records, in the Druze court, from 1931 to 1974.

Given the persistent nature of the patterns which have been documented here, we expect the institution of marriage among the Druze to follow the same basic form for many years to come. (Alamuddin and Starr $1980: 961$

\section{CLOSING REMARKS}

It is hoped that the research presented here will serve as a springboard for a more in-depth study of Druze marriages in the Shouf Mountains and elsewhere in the Middle East. Much more work is necessary to track the impact of changing political and economic conditions on Druze society, particularly in war-torn Lebanon. Only detailed ethnographic research, conducted over a long period of time, will make it possible to ascertain whether this resistance to change in basic marriage functions and patterns, by this unique, Middle Eastern ethnic minority, can be maintained. 
SELECTED REFERENCES

A Committee of the Royal Anthropological Institute of Great Britain and Ireland. 1967. Notes and Queries on Anthropology, 6th ed. Routledge and Kegan Paul, Ltd., London.

Abraham, A. J. 1981. Lebanon at Mid-Century: Maronite/Druze Relations in Lebanon 1840-1860. University Press of America, Washington, D.C.

Abu-Izzeddin, Nejla M. 1984. The Druzes: A New Study of Their History, Faith and Society. E. J. Brill, Leiden.

Alamuddin, Nura S. and Paul Starr. 1980. Crucial Bonds: Marriage Among the Lebanese Druze. Caravan Books, Delmar, NY.

Arberry, A. J., general ed. 1969. Religion in the Middle East, vol. 2. Cambridge at the University Press, London.

Ayoub, Millicent. 1959. Parallel Cousin Marriage and Endogamy: A Study in Sociometry. Southwestern Journal of Anthropology, vol. 15, no. 3, Autumn, pp. 266-275.

Barth, Fredrik. 1954. Father's Brother's Daughter Marriage in Kurdistan. Southwestern Journal of Anthropology, vol. 10, no. 2, Summer, pp. 164-171.

Betts, Robert Brenton. 1988. The Druze. Yale University Press, New Haven.

Brownstone, David M., Irene M. Franck and Douglass L. Brownstone. 1988. Island of Hope, Island of Tears. Viking Penguine, Inc., New York.

Chasseaud, George W. 1855. The Druses of Lebanon. Richard Bentley, London.

Clifford, James and George E. Marcus, eds. 1986. Writing Culture: The Poetics and Politics of Ethnography. University of California Press, Berkeley. 
Condor, Joseph. 1830. The Modern Traveler: Syria and Asia Minor, vol. 1. W. Clowes, London.

Crane, Julia G. and Michael V. Angrosino. 1974. Field Projects in Anthropology. General Learning Press, New Jersey.

Dana, Nissim. 1980. The Druse: a religious community in transition. Turtledove Publishing, Jerusalem.

Davis, Cullom, Kathryn Back and Kay MacLean. 1970. Oral History. The American Library Association, Chicago.

Davis, J. 1977. People of the Mediterranean. Routledge and Kegan Paul, Ltd., Boston.

Dwyer, Kevin. 1982. Moroccan Dialogues: Anthropology in Question. The John Hopkins University Press, Baltimore.

Eliade, Mircea, chief ed. 1987. The Encyclopedia of Religion, vol. 4. Macmillan Publishing Co., New York, pp. 503-506.

Fawaz, Leila Tarazi. 1983. Merchants and Migrants in Nineteenth Century Beirut. Harvard University Press, Cambridge.

Fernea, Elizabeth Warnock. 1969. Guests of the Sheik. Anchor Books, New York.

Fisher, Signey Nettleton. 1979. The Middle East, 3rd ed. Alfred A. Knopf, New York.

Fox, Robin. 1974. Kinship and Marriage. Penguin Books Ltd., Baltimore.

Georges, Robert A. and Michael O. Jones. 1980. People Studying People. University of California Press, Berkeley.

Guillaume, Alfred. 1956. Islam, 2nd ed. Reprint 1983, Penguin Books, London.

Gutman, David L. 1974. Alternatives to Disengagement: The old Men of the Highland Druze. Culture and Personality: Contemporary Readings, ed. Robert A. Levine. Aldine Publishing Co., Chicago, pgs. 232-245.

Hatab, Zuheir. 1982. Crisis of the Lebanese Family. The Jerusalem Quarterly, no. 25, Fall, Jerusalem, pgs. 2730 . 
Hitti, Philip K. 1928. The Origins of the Druze People and Religion. Columbia University Press, New York.

- 1957. Lebanon in History. MacMillan and Col., Ltd., London.

- 1977. History of the Arabs, 10th ed. St. Martin's Press, New York.

Howard, Michael C. 1986. Contemporary Cultural Anthropology, 2nd ed. Little, Brown and Co., Boston.

Joumblatt, Kamal. 1982. I Speak for Lebanon, trans. Michael Pallis. Zed Press, London.

Keesing, Roger M. 1975. Kin Groups and Social Structure. Holt, Rinehart and Winston, New York.

Khuri, Faud I. 1970. Parallel Cousin Marriage Reconsidered: A Middle Eastern Practice that Nullifies the Effects of Marriage on the Intensity of Family Relations. Man, no. 5, pgs. 597-618.

- 1975. From Village to suburb. The University of Chicago Press, Chicago.

Kuper, Adam, ed. 1977. The Social Anthropology of Radcliffe-Brown. Routledge and Kegan Paul, Ltd., Boston.

Langness, L.L. 1965. The Life History in Anthropological Science. Holt, Rinehart and Winston, New York.

Layish, Aharon. 1982. Marriage, Divorce and Succession in the Druze Family. E.J. Brill, Leiden.

Makarem, Sami Nasib. 1974. The Druze Faith. Caravan Books, Delmar, New York.

Mayer, Egon. 1975. Becoming Modern in Bayt Al-Shabab. Middle East Journal, Summer, pgs. 279-294.

Murphy, Robert F. and Leonard Kasdan. 1959. The Structure of Parallel Cousin Marriage. American Anthropologist, vol. 61, pgs. 17-29.

Nelson, Cynthia. 1974. Public and Private Politics: Women in the Middle Eastern World. American Ethnologist, vol. 1, no. 3, pgs. 551-563. 
Oppenheimer, Jonathan W.S. 1980. "We are Born in Each Other's Houses": Communal and Patrilineal Ideologies in Druze Village Religion and Social Structure. American Ethnologist, vol. 7, pgs. 621-636.

Parfit, Joseph K. 1917. Among the Druzes of Lebanon and Bashan. Hunter and Longhurst, Ltd., London.

Patai, Raphael. 1955. Cousin-Right in Middle Eastern Marriage. Southwestern Journal of Anthropology, vol. 11, no. 4, Winter, pgs. 371-390.

Pawkett, Jr., Lloyd E. 1978. The Druze Community of Greater Syria in the 20 th Century. University of La Verne, California, unpublished MA thesis.

Pelto, P.J. and Gretel H. Pelto. 1987. Anthropological Research: The Structure of Inquiry, 2nd ed. Cambridge University Press, New York.

Quale, G. Robina. 1988. A History of Marriage Systems. Contributions in Family studies, no. 13, Greenwood Press, Westport, Ct.

Salibi, Kamal S. 1977. The Modern History of Lebanon. Caravan Books, Delmar, New York.

Schusky, Ernest L. 1972. Manual for Kinship Analysis, 2nd ed. Holt, Rinehart and Winston, New York.

Seabrook, w.B. 1927. Adventures in Arabia. Blue Ribbon Books, New York.

Smith, W. Robertson. 1903. Kinship and Marriage in Early Arabia. Beacon Press, Boston.

Spindler, George D., ed. 1970. Being an Anthropologist: Fieldwork in Eleven Cultures. Holt, Rinehart and Winston, Inc., New York.

Spradley, James P. 1979. The Ethnographic Interview. Holt, Rinehart and Winston, New York.

Stark, Freya. 1942. Letters From Syria. John Murray, London.

Starr, Paul D. and Nura S. Alamuddin. 1984. The Marriage Contract: Bridewealth in Lebanon, Culture and Conflict: Readings in Cultural Anthropology, 5 th ed. Little, Brown and Co., Boston, pgs. 131-136. 
Sweet, Louse E. 1967. The Women of 'Ain Ad Dayr. Anthropological Quarterly, vol. 40, no. 3, July, pgs. 167-183.

- 1974. Visiting Patterns and Social Dynamics in a Lebanese Druze Village. Anthropological Quarterly, vol. 47, no. 1, January, pgs. 112-119.

Tweedie, W.K. 1870. Eastern Manners and Customs. T. Nelson and Sons, London.

Westermarck, Edward. 1914. Marriage Ceremonies in Morocco. Macmillan and Co., Ltd., New York. 


\section{APPENDIX}

The questions listed below are a sample of those asked

of a young Druze male in the Shouf Mountains of Lebanon.

1. You are engaged to be married in 1988. Please

describe the complete process, customs and traditions you followed in order to be engaged.

2. How old were you when it was decided that you should, or could, get married? Who decided? Was it you?

Your parents?

3. Please describe the exact process, all of the steps, that you went through to choose a girl to marry. What part did you play in choosing? What part did your family play in choosing?

4. If your looking for a bride was different from what is traditional, please describe in what way it was different.

5. Did you look at or consider many girls before you chose your wife? Is your fiance a relative of yours? If she is, what relationship is she to you? Is your fiance from the same village as you are? Which one?

6. (Questions regarding traditional vs. modern) What qualities did you look for in choosing a wife? What makes a good wife within your religious beliefs? How 
did you decide this girl was right for you? How old is your fiance?

7. Did your mother and father play an important part in finding your wife, in seeing if she was the right girl to approach for marriage?

8. Did your brothers and sisters (if any) help with approaching the girl and her family?

9. Did you speak to the girl directly or to her parents first? Or did your parents, or a relative, speak to her family first? Please describe what happened.

10. How soon was it before your fiance expressed an interest in your proposal? Or was the interest from her family? Was the girl allowed to say yes or no? Could she make her own choice, or was it made by her parents or family? Who told you?

11. Can a man make his own choice, or is it made by his parents or family? Who told you about this choice?

12. How did you see each other after you decided to marry? Were you, or are you, ever allowed to be alone? Do you need a chaperon? If yes, is it always necessary? Who is considered a good chaperon?

13. Where are you allowed to go? How long did yqu see each other before you decided to become engaged? What is the traditional time? Has it changed?

14. What is the usual time to be engaged? Would you speed up the process if you lived abroad? 
15. Please describe the next step in your marriage process, after your fiance and her family accepted your proposal of marriage? When was the mahr decided on? Who decided what amount it would be? What was the mahr that you will (or have) paid? If you are still engaged, has all of your mahr been paid? If not, why not? What is left to pay or give?

16. Is it difficult to agree on a mahr? Who is involved in the process? Please describe the negotiations for your mahr? Who was involved in your process?

17. What is the next step after the mahr is decided upon? Please describe it, and give all the Arabic words or phrases for each step.

18. Have you ever heard of a woman being forced to marry a man she did not want to marry? Have you ever heard about a woman being captured for marriage?

19. Please describe the day you went to register the marriage contract. Where was this done? Who was present? When was the delayed mahr recorded? Who was it given to? Who has your record of delayed mahr?

20. What is the next step in a Druze wedding after the marriage contract is registered? Please give the Arabic words for all of the steps. Can there be a delay between the day the marriage contract is registered and the day the wedding celebration is 
held? If so, how long can the delay be? What is traditional?

21. Please describe your wedding day, or if you are not married yet, please describe what you expect it will be like. If you are not married yet, can you describe any wedding that you participated in or attended in the past?

22. For your wedding day, how were you dressed? How was the bride dressed? What did you do to get ready for the wedding? When did you see your bride? Where was she? How was she dressed? Who was with her? Who was with you?

23. Where was the actual wedding celebration held? Did you have to transport your bride there? Was her family there too? Who was present for this celebration? Was there food, if so, what kind? Who prepared it? Did you have alcohol? Was there music? Dancing? Who danced? How long did the celebration last?

24. Did you receive any wedding gifts? If so, what were they? Who gives wedding gifts? Where are they presented? Are they seen at the wedding celebration? Did the bride make any handcrafted items for your new home?

25. Can you please describe how your wedding might have been different, if at all, from a traditional wedding? 
26. Where did you and your bride go after the wedding celebration? Where did you have your first home? Did you have a choice of where to live? Do you live with your parents? Where is the traditional place to live? Is this changing at all? If so, what do you think is causing the change? 


\section{Biographical Data Sheet for Informant}

Family Name
Father's Father's Name Father's Mother's Name
Place of Birth

\section{Father's Name \\ Mother's Father's Name}

Age of Person Interviewed

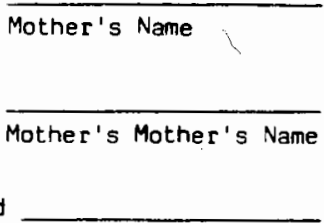

Village

Raised in the city or country (mountain)

Number of years in the mountain or city

What does this person do for a living? (Farmer, owns a shop, homemaker, etc.?)

Language spoken from birth?

Father's language

Does this person read? Yes or No

Is this person married? Yes or No

Spouse's Father's Name

Spouse's Father's Father's Name

Spouse's religion

Spouse's ethnic background

Mother's language

Spouse's name

Does this person have any children? Yes or No

If there are children, how many ojys and how many girls? What ages are the children?

Other language(s) of person

Does this person write? Yes or No

Spouse's Mother's Name

Spouse's Mother's Mother's Name

How many married sons?

How many married daughters?

Does this person have any graddaughters? Yes or No

Does this person have any grandsons? Yes or No

Has this person participated in any marriage process (when, where, what, who, etc.)?

\footnotetext{
Is this person a sheik or sheika? Yes or No
}

Is this person's spouse a sheik or sheika? Yes or No

Describe the differences in a sheik/sheika marriage process 